\title{
Prioritizing native migratory fish passage restoration while limiting the spread of invasive species: A case study in the Upper Mississippi River
}

\author{
Arthur R. Cooper ${ }^{a^{*}}$, Dana M. Infante ${ }^{a}$, Jesse R. O’Hanley ${ }^{b, c}$, \\ Hao $\mathrm{Yu}^{\mathrm{a}}$, Thomas M. Neeson ${ }^{\mathrm{d}}$, Kyle J. Brumm ${ }^{\mathrm{a}}$
}

${ }^{a}$ Department of Fisheries and Wildlife, Michigan State University, USA

${ }^{\mathrm{b}}$ Kent Business School, University of Kent, UK

${ }^{c}$ Durrell Institute of Conservation and Ecology, University of Kent, UK

${ }^{\mathrm{d}}$ Department of Geography and Environmental Sustainability, University of Oklahoma, USA

*Corresponding author: coopera6@msu.edu

Department of Fisheries and Wildlife, Michigan State University

Manly Miles Building, Suite 318, East Lansing, MI, 48823, USA 


\section{ABSTRACT}

Despite increasing efforts globally to remove dams and construct fish passage structures, broad-scale analyses balancing tradeoffs between cost and habitat gains from these mitigations infrequently consider invasive species. We present an optimization-based approach for prioritizing dam mitigations to restore habitat connectivity for native fish species, while limiting invasive species spread. Our methodology is tested with a case study involving 240 dams in the Upper Mississippi River, USA. We integrate six native migratory fish species distribution models, distributions of two invasive fishes, and estimated costs for dam removal and construction of fish passes. Varying budgets and post-mitigation fish passage rates are analyzed for two scenarios: 'no invasives' where non-selective mitigations (e.g., dam removal) are used irrespective of potential invasive species habitat gains and 'invasives' where a mixture of selective (e.g., lift-and-sort fish passage) and non-selective mitigations are deployed to limit invasive species range expansion. To achieve the same overall habitat connectivity gains, we find that prioritizations accounting for invasive species are 3 to 6 times more costly than those that do not. Habitat gains among native fish species were highly variable based on potential habitat overlap with invasive species and post-mitigation passabilities, ranging from $0.4-58.9 \%$ ('invasives') and 7.9-95.6\% ('no invasives') for a \$50M USD budget. Despite challenges associated with ongoing nonnative fish invasions, opportunities still exist to restore connectivity for native species as indicated by individual dams being frequently selected in both scenarios across varying passabilities and budgets, however increased restoration costs associated with invasive species control indicates the importance of limiting their further spread within the basin. Given tradeoffs in managing for native vs. invasive species in river systems worldwide, our approach demonstrates strategies for identifying a portfolio of candidate barriers that can be 
investigated further for their potential to enhance native fish habitat connectivity while concurrently limiting invasive species dispersal.

Keywords: dams, river fragmentation, barrier mitigation, prioritization, species distribution models 


\section{INTRODUCTION}

Habitat connectivity is essential for supporting organism fitness and sustaining populations and, therefore, is a critical factor for long-term species persistence (Hanski, 1999; Baguette et al., 2013). In fluvial systems, where aquatic organisms such as fishes are constrained to living and navigating within dendritic river networks (Fagan, 2002; Campbell Grant et al., 2007), anthropogenic barriers can adversely disrupt connectivity and fragment habitats (Nilsson et al., 2005; Liermann et al., 2012). For migratory fishes, habitat connectivity is particularly important as individuals often move long distances within river networks to utilize disparate habitats for rearing, spawning, and refugia access (Schlosser and Angermeier, 1995; Lucas and Baras, 2001). However, migratory fishes inhabiting large rivers often face severe loss of longitudinal (and lateral) connectivity (Cooke et al., 2012), as large rivers are frequently the most fragmented by dams (Cooper et al., 2017). Globally, there has been increased investment in dam removals and building fish passage structures (O'Connor et al. 2015; Silva et al., 2018) to reopen critical migratory fish pathways.

In many cases, promoting habitat connectivity for native species conflicts with the need to preclude movement and spread of invasive species (Rahel, 2013). In fluvial ecosystems, this "connectivity conundrum" (Zielinski et al., 2020) occurs where dam removal or construction of fish passes facilitates dispersal not only for desirable native species but also invasive species that can cause economic and/or ecological harm within reconnected streams (McLaughlin et al., 2013; Rahel, 2013). To tackle this challenging problem, approaches that identify dam mitigation opportunities favoring native species despite potential or ongoing invasions are needed (Galat and Zweimüller, 2001; Rahel, 2013; Rahel and McLaughlin, 2018). However, such approaches have rarely been applied (Kerr et al., 2021), particularly at the broad spatial extents over which 
long-distance native freshwater fish migrations occur. A notable exception is the decades-long management of invasive sea lamprey (Petromyzon marinus) in the Laurentian Great Lakes in part through use of low-head dams to block their upstream movement (Lavis et al., 2003). Despite successfully limiting sea lamprey spawning, these efforts are increasingly recognized as constraining other fish species from accessing key habitats, thus underscoring the need to restore fish passage for desirable fishes while managing the spread of invasives (Vélez-Espino et al., 2011; Milt et al., 2018; Lin et al., 2019). Restoring connectivity under such circumstances involves identifying locations where non-selective mitigation (e.g., dam removal) versus selective passage strategies for desirable species would be most effective (Rahel and McLaughlin, 2018). Successful approaches for evaluating tradeoffs invariably needs to rely on vital information to guide when, where, and how to deploy different mitigation actions, including estimation of project cost and suitability of reconnected habitats, which is likely to prove particularly challenging in the case of migratory fish species whose migratory pathways can span long distances and many dams located in different management jurisdictions (e.g., Pracheil et al., 2012, Tripp et al., 2019).

Dam prioritization using an optimization-based approach is well-suited to address this problem. Optimization is ideally suited for evaluating complex barrier mitigation problems (Kemp and O’Hanley, 2010) in order to maximize potential habitat connectivity gains given limited financial and/or other resources (e.g., Neeson et al., 2015). Optimization modeling has the capacity to evaluate large numbers of dams spanning multiple jurisdictions (Neeson et al., 2015; Milt et al., 2017) and account for multiple available projects (e.g., dam removal vs. fishway construction) that differ in terms of economic costs and anticipated species habitat gains at each dam site. An important component of optimization includes the integration of differing 
fish passage rates among projects at dam locations along with their combined effects on cumulative fish passage. This ability to evaluate cumulative passability through a series of dams is particularly important for migratory species due to the interactive effect of mitigation actions, as any single mitigation action has a cascading effect on increased habitat accessibility and relative benefit (i.e., habitat gain) provided by other potential mitigation projects within the river system (Kemp and O'Hanley, 2010). Accurately representing this spatially complex problem requires the integration of habitat influences from numerous dams producing a mosaic of fragmented habitats of differing abiotic suitability for multiple species of interest (e.g., Wiens, 2002).

For native fish species, dam mitigations are only successful if they reconnect suitable habitats (Pompeu et al., 2012; McLaughlin et al., 2013). This highlights the need for approaches that adequately represent potential habitat gains when assessing mitigation options (Crook et al., 2015). Approaches that use generic structural connectivity measures (i.e., total accessible stream network length) as proxies for habitat gain result in less efficient, more costly solutions (Sethi et al., 2017; Rodeles et al., 2020), prompting calls to move towards functional connectivity measures in dam prioritizations (Branco et al., 2014). Increasingly, prioritizations have utilized functional connectivity measures representing fish diversity, richness, populations, and life history traits (Erős et al., 2018; Ioannidou and O'Hanley, 2019; McManamay et al., 2019; Kemp et al., 2020, King et al., 2021), but attempts to address functional connectivity in dam prioritizations incorporating habitat suitability for individual species have often relied on species ranges. However, relying solely on species range data can result in large potential commission errors and inadequate estimates of habitat overlap with invasive species, as all stream habitat accessible within a species' range is treated as equally suitable (McKay et al., 2017) irrespective 
of differences in actual habitat quality of different stream segments. Species distribution models (SDMs) have been utilized to predict species habitat for a variety of fish conservation applications (e.g., Taylor et al., 2018). Coupling SDMs with dam prioritizations, while rarely used (see Branco et al., 2014), can improve estimates of functional connectivity gains among mitigation projects and provide a means of accounting for habitat suitability when prioritizing for one or more species.

Here we present an approach that combines species distribution models for native species, estimated dam removal and fish pass construction costs, and distributions of invasive species to prioritize fish passage mitigation projects. We test our approach using six imperiled native migratory fishes and two invasive bigheaded carp species (Hypophthalmichthys nobilis and $H$. molitrix) obstructed by 240 dams in the Upper Mississippi River, USA. Specifically, we: 1) quantify species habitat using modeled distributions for native fishes and known current distributions for invasive species, 2) use dam locations to characterize species-level habitat fragmentation, 3) develop cost estimates for dam removal and fishway construction, and 4) utilize this information in optimized dam mitigation planning aimed at enhancing native fish habitat connectivity according to two contrasting scenarios: 'no invasives' where potential mitigation actions do not consider current bigheaded carp distributions and 'invasives' where selective mitigation actions are used to limit bigheaded carp dispersal. We use these results to ask: Are there opportunities to improve connectivity for native migratory fishes despite ongoing fish invasions? Our approach can be utilized for the conservation of native species by better understanding tradeoffs between cost and habitat gains in rivers undergoing invasions when designing dam removal/mitigation strategies. 


\section{METHODS}

\subsection{Study area}

The Upper Mississippi River (UMR), including its many large tributaries and their headwaters, is a highly complex social-ecological system that supports both high biological diversity and numerous ecosystem services (Bouska et al., 2018). Variability in natural landscape conditions within the region (e.g., glacial/non-glacial landforms, geology, and climate) has resulted in a wide range of chemical, hydrologic, and thermal conditions among streams (Wang et al., 2001; Lyons et al., 2009; De Jager and Houser, 2016). This range in stream conditions has given rise to a diversity of fishes occurring within the basin, with over 140 fish species identified (Garvey et al., 2010). The UMR and the basin it drains supports numerous socioeconomic activities including commercial and recreational fisheries (Garvey et al., 2010, Klein et al., 2018), extensive agricultural production, and urban development (Bouska et al., 2018). Dams located throughout the UMR provide economic benefits such as shipping, hydropower generation, and recreation, however, they have also resulted in extensive stream habitat fragmentation along the UMR mainstem and tributaries (Cooper et al., 2017). Given the emphasis on potential dam mitigation options for the current study, we focused on the dammed portion of the UMR, starting from the lowest dam on the UMR mainstem (Lock and Dam 26) just above the confluence of the Missouri River (Figure 1). In total, the study area includes $289,300 \mathrm{~km}$ of streams (USEPA and USGS, 2015) and a land area covering 447,394 $\mathrm{km}^{2}$.

\subsection{Characterizing stream fragmentation}

Large dams generally defined as $>1.8 \mathrm{~m}$ in height (Cooper et al., 2017) obtained from the 2012 National Anthropogenic Barrier Database (NABD; Ostroff et al., 2013) were used to 
identify barriers to migratory fish in the UMR basin. Of the initial 2,593 dams located within the study region, we identified 29 dams that have been either removed or breached since the NABD dataset was created (American Rivers, 2020). These dams were subsequently removed from our list of dams, thus resulting in a revised dataset of 2,564 dams. The 1:100,000 scale National Hydrography Dataset Plus Version 2 (NHDPlusV2; USEPA and USGS, 2015) was used to represent a confluence-to-confluence stream network for the UMR (Wang et al., 2011). To quantify stream fragmentation, we utilized existing methods to delineate river subnetworks bounded by dams (see Cooper et al., 2017), termed 'patches' in this study (but also known as 'functionally connected stream networks'; Anderson et al., 2013). Patches represent contiguous, connected sections of stream network located between large dams, while patch catchments represent the land area draining to stream reaches within a patch (Cooper et al., 2017; Figure 1a). These patches and their catchments were used to quantify species-level habitat fragmentation based on predicted habitat suitability within patches and define habitat availability within patches as inputs to barrier prioritizations (explained below).

\subsection{Developing species distribution models and quantifying species level habitat}

\section{fragmentation}

Distributions models were developed for six species in three families (Table 1). These included paddlefish (Polyodon spathula), lake sturgeon (Acipenser fulvescens), shovelnose sturgeon (Scaphirhynchus platorynchus), blue sucker (Cycleptus elongatus), river redhorse (Moxostoma carinatum), and greater redhorse (Moxostoma valenciennesi). These species were chosen because they are considered highly migratory fishes (Bunt and Cooke, 2001; Reid, 2006; Neely et al., 2009; Hupfeld et al., 2016; Tripp et al., 2019), representing ideal targets for barrier 
mitigation, and because they are listed as Species of Greatest Conservation Need (SGCN) by two or more states within the study basin (USGS, 2015).

Fish presence-absence data were obtained from a national dataset (see Yu et al., 2020) developed from fish sampling surveys by federal, state, and academic institutions and georeferenced to the NHDPlusV2 stream network. Due to limited presence-absence data for lake sturgeon and paddlefish (i.e., $<50$ fluvial presences), additional presence-only data were acquired from the Global Biodiversity Information Facility (GBIF, 2020a; GBIF, 2020b) and Montana Fish, Wildlife \& Parks for paddlefish (MTFWP, 2020). In total, 57 and 42 presenceonly locations were available for lake sturgeon and paddlefish, respectively (Table 1). We used two commonly applied machine learning algorithms to develop species distribution models (SDMs). These included boosted regression trees (BRTs) when presence-absence data were available (Elith et al., 2008) and MaxEnt when presence-only data were available (Phillips et al., 2006). These approaches use machine-learning techniques to model complex species-habitat relationships in the development of SDMs. BRTs were used to develop SDMs for shovelnose sturgeon, blue sucker, river redhorse, and greater redhorse, while lake sturgeon and paddlefish SDMs were modeled with MaxEnt (Table 1).

For both SDM approaches (BRT and MaxEnt), models were built using data across their entire native ranges, including data occurring outside the study area (Figure S1). In all, 22 predictors variables representing both natural and anthropogenic landscape conditions frequently utilized in fluvial fish SDMs were included (Table S1; Cooper et al., 2019, Yu et al., 2020). Model efficacy for both approaches was evaluated using the area under the receiver operating characteristic curve (AUC; Swets, 1988) values based on 10-fold cross-validation, a technique that partitions data into 10 unique test sets that are withheld for model validation while 
remaining training sets are used for model development. Model predictions were used to map predicted presence at stream reaches within each species' native range, with the prevalence method used as the threshold for presence/absence predictions for BRTs (Liu et al., 2005) and the $10^{\text {th }}$ percentile training occurrence used as the cutoff for MaxEnt (Daniel et al., 2018). Predicted presences for stream reaches were mapped to quantify both the total amount of predicted habitat (in river kilometers) within the study basin as well as the amount of habitat located within individual patches (Figure S2).

\subsection{Acquiring mitigation cost data and estimating dam removal and fishway construction} costs

Based on a literature review, removal costs $(n=101)$ and fishway construction costs $(n=$ 62) for large dams were gathered for the conterminous USA and used in model development (Tables S2 and S3). Costs for dam removals and fishway construction projects were obtained from a variety of sources, including government reports, gray literature, and news publications. Due to a range of years from which cost data originated (1986-2020), an inflation calculator (https://www.bls.gov/data/inflation_calculator.htm) was used to convert dam removal and fishway costs to 2020 U.S. dollars.

We developed generalized additive models (GAMs) to estimate dam removal and fishway construction costs for dams within the UMR. GAMs are semi-parametric extensions of generalized linear models (GLMs) that replace predictor variables with smoothing functions (Hastie and Tibshirani, 1986) and are better suited for modeling non-linear or non-monotonic relationships between response and predictor variables (Guisan et al., 2002). GLMs were first developed using 11 candidate quantitative and categorical predictors. These included four dam attributes representing dam height, age, length, and reservoir storage volume and four categorical 
variables describing dam type, main purpose, ownership, and hazard status (Table 2). In addition, three stream reach predictors obtained from the NHDPlusV2 dataset were used, including stream gradient, stream order, and estimated annual discharge. All numerical predictors were log transformed prior to model development. GLMs for dam removal and fishway construction were generated using a forward stepwise approach by selecting the model with the smallest Akaike information criteria (AIC) value. Final GAM models were developed based on the set of predictor variables identified by the best GLM models. Models were subsequently checked for normality and homoscedasticity of the residuals. Both GLM and GAM models were developed using the R (version 3.6.1, R Core Team, Vienna, Austria) package mgcv.

In addition to predicting costs for conventional fishways, we estimated costs to install lift-and-sort fish passage structures. These are structures that have elevator-like mechanisms to lift fish over dams, with native or desirable fish being manually sorted and placed upstream by fisheries technicians and non-native species excluded. Due to lack of cost data for these structures for predictive modeling, we used a static cost of $\$ 23.7 \mathrm{M}$ (USD) per structure based on maximum cost (rounded for inflation) identified from several structures with cost information (Table S4). We chose this figure due to potential increased costs associated with technical and engineering aspects associated with large dams (Wilcox et al., 2004). This fish passage option was utilized in prioritization scenarios accounting for invasive species (described below).

\subsection{Optimizing dam mitigation}

\subsubsection{Estimating the distribution of invasive fish species}

Establishment of invasive bighead carp (Hypophthalmichthys nobilis) and silver carp (Hypophthalmichthys molitrix) within the UMR have resulted in declines of native game species 
(Chick et al., 2020), shifts in fish size and biomass (Bouska et al., 2020), and reduction in body condition for paddlefish (Kinlock et al., 2020). Further, dispersal capabilities of these invasive species are comparable to native migratory species (i.e., paddlefish and lake sturgeon,

DeGrandchamp et al., 2008), making their exclusion from uninvaded habitats paramount to their management within the UMR. To account for these two invasive fishes in the study basin, known occurrences of bighead carp ( $n=1,444$; USGS, 2020a) and silver carp $(n=3,183$; USGS, 2020b) were used to develop an estimated distribution representing both species (hereafter referred to as 'bigheaded carps'). This distribution was created by mapping all occurrences of bigheaded carps to delineate stream reaches with potential habitat within the study basin (Figure S3). By including all occurrences, the resulting distribution represents both lower sections of the UMR where bigheaded carps are known to be well established as well as potential establishment in upper sections of the UMR where occurrences correspond to upstream advancement and evidence of spawning has been observed (Larson et al., 2017). This estimated distribution was used to quantify potential habitat overlap with the six native migratory fishes in this study as well as to constrain dam prioritization scenarios involving invasive species (described below).

\subsubsection{Optimization scenarios - no invasives vs. invasives}

Two primary optimization scenarios were compared (Figure 2). This included a 'no invasives' scenario where mitigation options focused solely on enhancing native migratory fish habitat connectivity irrespective of potential bigheaded carp movement and an 'invasives' scenario where dam mitigation options for enhancing native migratory fish habitat connectivity also attempt to minimize invasive bigheaded carp movement. To generate these scenarios, we first used primary dam purposes to identify dams not likely to be removed (including dams that 
generate hydroelectric power and promote navigation) and where fish passage structures were considered the only restoration option. This step acknowledges that dam removal is not a realistic option for certain dams serving critical societal needs (Kocovsky et al., 2009; Hoenke et al., 2014) and was used to constrain overall mitigation options prior to running 'no invasives' and 'invasives' scenarios. Under the 'invasive' scenario, all dams identified as blocking upstream movement of bigheaded carps were constrained to the lift-and-sort fish passage mitigation option only. All other dams were assigned fishway only or fishway/dam removal options depending on dam purpose (describe above). For the 'no invasives' scenario, lift-and-sort structures were not considered and dam mitigation options were similarly identified based on primary dam purpose.

\subsubsection{Optimization approach and parameters}

To systematically choose among dam removal and fishway passage mitigation options, we adopted an optimization-based approach. Optimization is a sophisticated approach to decision making that has advantages over other types of prioritization methods due to its ability to identity the most efficient (i.e., optimal) use of limited resources. Our mixed integer linear programing model was coded in the Optimization Programming Language (OPL) using CPLEX Studio v12.10 software (IBM, 2020). Optimization models such as ours are useful in evaluating multiple mitigation actions at each barrier location (i.e., dam removal or fishway construction) and accounting for the interactive effects of dam mitigation actions on cumulative passability. This leads to more robust solutions than other approaches that typically consider a single mitigation option and/or each mitigation decision in isolation, thus ignoring the spatial structure of river barrier networks (Kemp and O’Hanley, 2010; McKay et al., 2017). 
In the context of this study, optimizations were utilized to identify solutions that maximize native fish habitat gains for a given budget. Inputs to the optimization included predicted habitat lengths within patches, mitigation cost(s) at each dam location, and pre- and post-passability estimates, which correspond to the level of fish passage at each structure before and after mitigation. The amount of upstream habitat above each dam was set to the predicted suitability habitat length for each species based on habitat suitability models. Costs for dam mitigation, including dam removal, fishway construction, and lift-and-sort fish passage, were assigned to each dam based on model predictions in both 'no invasives' and 'invasives' scenarios. Pre- and post-passability of barriers are scaled from $0 \%$ (completely impassable) to $100 \%$ (fully passable). For the potamodromous (within-basin) migration patterns considered in this study, both upstream and downstream passabilities are considered when determining an overall passability value for each dam. In assigning pre-passability for 35 lock and dam structures on the Mississippi and Illinois Rivers, we primarily used data from Bouska et al. (2019), who calculated the average percentage of time that gates at lock and dam structures were open during the 1985-2015 period. For four lock and dams without data, we based our estimates on Wilcox et al. (2004), who suggested that the uppermost lock and dam structures on the Mississippi River (St. Anthony Falls Upper/Lower and Lock and Dam 1) were either closed or impassible and on Snyder (2019), who carried out a microchemistry analysis of fish passage for Catostomidae species in the Illinois River (Brandon Road Lock and Dam). For one remaining lock and dam on the Illinois River lacking information (Lockport Powerhouse Lock and Dam), we used the average passability of all other lock and dam structures. For all other dams without locks, we assigned a $0 \%$ pre-passability. 
To account for variability of the potential effectiveness of fishway and lift-and-sort structures, we ran a series of experiments with different post-mitigation passabilities representing low, moderate, and high rates of fish passage. Post-mitigation passabilities for fishways were set at 25,50 , and $75 \%$ based on the range of reported passabilities for migratory fishes at these structures (Bunt et al., 2012; Noonan et al., 2012). Similarly, we set overall post-mitigation passabilities at 20,40, and $60 \%$ for lift-and-sort structures, which falls within the range of passabilities reported in the literature (Noonan et al., 2012). For lock and dams, the above percentages were added to existing pre-passabilities values, with maximum passability values capped at $100 \%$. Dam removals were given a post-passability of $100 \%$.

The optimization approach utilized in this study allows for multiple species to be simultaneously evaluated with optional weightings applied to different species. Species were weighted by the number of states listing that species as a 2015 SGCN within the study basin (Table 1). Finally, to generate cost-benefit curves of fish passage mitigation for both scenarios under low, moderate, and high post-mitigation passabilities, we ran optimizations for budgets between $\$ 1$ and \$500M USD at intervals of \$1M USD. Resulting cost-benefit curves compare the length of migratory fish habitat connectivity gained over varying budgets.

\section{RESULTS}

\subsection{Species distribution models and quantifying stream habitat fragmentation}

AUC values ranged from $0.90-0.98$ among species, indicating high SDM predictive accuracy (Table 1). Partial dependence plots for SDMs showed a positive relationship between model fitted functions and distance to the nearest downstream mainstem dam for all six migratory species, indicating increased suitability with increasing downstream mainstem habitat 
availability (Figure S4). Total predicted habitat lengths ranged from 2753 to 8601 river

kilometers (rkm) among species (Table 3). When predicted habitats were mapped with respect to dam locations, 240 of the 2,564 dams (9.4\%) in the study region were identified as restricting upstream and downstream habitat connectivity for one or more species. Fragmentation caused by these dams has resulted in predicted habitats across species being divided into 44-175 total patches of varying predicted habitat lengths (i.e., $>25,>50$, and >100 rkm), showing the degree to which native migratory fish habitats are disconnected in the study basin (Table 3). In particular, only 7 and 9 patches contain greater than $100 \mathrm{rkm}$ of predicted habitat for lake sturgeon and paddlefish, respectively. For bigheaded carps, $3599 \mathrm{rkm}$ of habitat is estimated within the basin among 44 river patches. Comparisons of estimated bigheaded carp habitat and predicted habitats for native migratory fish species indicated a varying degree of potential habitat overlap within the study basin (Table 4). Paddlefish, blue sucker, and shovelnose sturgeon had the highest overlap, ranging from 55-67\% of total habitat length and 57-77\% of river patches. Overlap was much lower for lake sturgeon, river redhorse, and greater redhorse, ranging from $10-24 \%$ of total habitat length and $14-28 \%$ of river patches.

\subsection{Dam removal and fishway construction cost estimates}

Forward stepwise selection of predictors for the GLM dam removal cost model selected dam height, dam age, estimated stream discharge, and dam type, which were then used in the final GAM model for dam removal costs $\left(\mathrm{R}^{2}=0.71\right)$. Results for individual predictors indicated that increased dam height, dam age, and estimated annual stream discharge resulted in increased dam removal costs (Figure 4a), while arch and concrete buttress dams are more expensive to remove than other dam types (e.g., earthen, timber crib, concrete, etc.). Stepwise selection of predictors for fishway cost selected dam height, estimated stream discharge, and dam type 
resulting in a final GAM model with an $\mathrm{R}^{2}=0.59$. Similar to dam removal cost, partial dependence plots of dam height and estimated stream discharge generally showed increases in fishway construction costs with increased dam height and stream discharge (Figure 4b).

Of the 240 dams impairing fish connectivity in the study basin, 111 dams were identified under the 'no invasives' scenario as candidates for either dam removal or fishway construction, with dam removal cost estimates averaging \$1.44M USD ( $\mathrm{sd}=\$ 2.09 \mathrm{M})$ and fishway construction cost estimates averaging $\$ 1.34 \mathrm{M}(\mathrm{sd}=\$ 1.46 \mathrm{M})$. For 129 additional dams where only fishways were considered (i.e., hydroelectric and lock dams), fishway costs averaged $\$ 7.20 \mathrm{M}(\mathrm{sd}=\$ 8.71 \mathrm{M})$. Under the 'invasives' scenario, 100 dams were identified as candidates for either dam removal or fishway construction, with averages of $\$ 1.46 \mathrm{M}(\mathrm{sd}=\$ 2.19 \mathrm{M})$ for dam removal and $\$ 1.22 \mathrm{M}(\mathrm{sd}=\$ 1.42 \mathrm{M})$ for fishway construction. Another 85 dams where only fishway construction was considered had estimated costs averaging $\$ 3.49 \mathrm{M}(\mathrm{sd}=\$ 3.09)$, while 55 remaining dams that were either restricting movement among existing habitats or blocking upstream advancement of bigheaded carps were given a static cost of $\$ 23.7 \mathrm{M}$ for lift-and-sort passage structures (see methods).

\subsection{Optimization results for the 'no invasives' vs. 'invasives' scenarios}

As expected, vastly different results were found for the 'no invasives' and 'invasives' scenarios. Cost-benefit curves for 'no invasives' and 'invasives' scenarios reveal that that scenarios involving mitigation options aimed at limiting the spread of invasive bigheaded carps ('invasives' scenario) yield much lower habitat gain for any given budget level than when only non-selective dam removal and fishway construction mitigation options are considered ('no invasives' scenario; Figure 5). Indeed, habitat gains up to a budget of $\$ 100 \mathrm{M}$ for a given postmitigation passability level (i.e., low, moderate, or high) under the 'invasives' scenario were 
generally half or less of those under the 'no invasives' scenario. For instance, with a budget of $\$ 50 \mathrm{M}$ and high post-mitigation passabilities for fish passage structures, potential habitat gains were $\sim 60 \%$ for 'no invasives'scenario compared to $\sim 20 \%$ for 'invasives' scenario. Comparing costs for habitat gains ranging from $10-50 \%$ for low, moderate, and high post-mitigation passabilities indicates that optimizations accounting for invasive species are 3-6 times more costly than optimizations that do not consider invasive species (Table 5). In addition, comparison of mitigation options (i.e., dam removal, fishway construction, and lift-and-sort fish passage) indicates that dam removals are more frequently selected at lower budgets, whereas fishways and lift-and-sort fish passage structures are increasingly favored at higher passabilities and budgets (Figure S7).

Similarly, habitat gains for individual species also differed between scenarios, with greatly diminished potential habitat gains under the 'invasives' scenario for most species (Figure 6). Substantial differences between the 'no invasives' and 'invasives' scenarios occurred for paddlefish, shovelnose sturgeon, and blue sucker. For these species, potential habitat gains based on the 'invasives' scenario with high passabilities were either comparable or lower than gains under the 'no invasives' scenario with moderate passabilities. Further, under the 'invasives' scenario with low passabilities, gains for these species were minimal (e.g., 10-25\% range) even with large budgets, demonstrating very limited mitigation opportunities due to the need to opt for less efficient fish passage structures instead of dam removals. Larger potential habitat gains were observed for lake sturgeon, river redhorse, and greater redhorse under the 'invasives' scenario. However, even for these species, gains were more limited under the 'invasives' scenario compared to the "no invasives' scenario. Greater redhorse had the highest potential gains of any species due to a combination of having the greatest amount of predicted habitat and the least 
habitat overlap with bigheaded carps. Overall, habitat gains among species varied based on potential habitat overlap with invasive species and post-mitigation passabilities, ranging from $0.4-58.9 \%$ for the 'invasives' scenario and $7.9-95.6 \%$ for the 'no invasives' scenario given a $\$ 50 \mathrm{M}$ USD budget. Differences in results between scenarios given low, moderate, and high postmitigation passabilities highlight the importance of fish passage efficacy for alternative mitigation projects in maximizing potential habitat gain (Figure 6).

Comparison of the number of times a dam was selected for mitigation action across budgets in the range $\$ 1-500 \mathrm{M}$ (dam removal or fish passage structure) for the 'invasives' and 'no invasives' scenarios showed the spatial influence of bigheaded carps on optimization results (Figure 7). Dams selected for mitigation in the 'no invasives' scenario included those along the Mississippi River mainstem and lower tributaries, however for the 'invasives' scenario, many of these dams were excluded in favor of mitigating dams located outside of the current bigheaded carp distribution. The comparison also highlighted dams that were regularly included in both 'no invasives' and 'invasives' scenarios, mainly dams found in the upper tributaries of the Mississippi River above the current distribution of bigheaded carps (e.g., dams along the Saint Croix River and upper tributaries), but also some mainstem (e.g., Lock and Dam 3, 18, and 19) and large tributary dams that could be managed for selective passage to exclude bigheaded carps. Certain dams were selected in more than $99 \%$ of optimization runs across budgets, indicating that mitigation of these dams have great potential to enhance river connectivity even at lower budgets.

\section{DISCUSSION}

In this study, we combined native fish species distribution models, known distributions of two invasive fish species, and predicted mitigation costs for dam removals and fishway 
construction to target connectivity restoration for multiple migratory fish species of conservation importance. Our work represents an advancement over previous efforts that typically focus on one or a handful of desirable species, account for at most one invasive species, consider only anadromous migration patterns, and only consider one mitigation option (e.g., dam removal) at dam locations. We developed an approach to plan barrier mitigations over a broad spatial extent encompassing the Upper Mississippi River, likely leading to greater efficiencies in identifying potential habitat gains as compared to analyses conducted at individual jurisdictions such as states (Neeson et al., 2015; Milt et al., 2017). For migratory fish species, there is a clear need for managing these species with long distance migratory pathways spanning multiple jurisdictions (Jager et al., 2016; Tripp et al., 2019) and intersected by hundreds of dams within a large river system as in the current study. Methods presented here can be used to identify a portfolio of dams that can be scrutinized in finer detail, allowing analysis of potential mitigation projects to include factors that are less readily quantifiable. This includes feedback of experts with local knowledge of river systems and biotic conditions. In such a process, broad-scale assessments such as that provided by this study can provide a means of reducing a large set of potential projects to a much smaller and manageable shortlist of projects that can be evaluated with locally available information and expertise. Ultimately, assessments involving broad- and local-scale information can more effectively identify potential dam mitigation projects by evaluating various ecological and economic tradeoffs that can range in scale from the management of individual dams (e.g., Turney, 2020) to basin-wide evaluations (e.g., Milt et al., 2018).

Our case study in the UMR comparing mitigation costs between the 'no invasives' and 'invasives' scenarios indicated that costs are 3 to 6 times higher to achieve a desired level of connectivity enhancement when invasive species are considered. Comparison among species 
showed large differences both within and among species depending upon scenario and postmitigation passability levels. For species with a high degree of potential habitat overlap with invasive bigheaded carps, such as paddlefish, shovelnose sturgeon, and blue sucker, potential habitat gains achieved under the 'invasives' scenario were greatly diminished compared to the 'no invasives' scenario. These results not only highlight the importance of limiting further bigheaded carp spread within the UMR which would further limit opportunities of increasing habitat connectivity for native species but also emphasize the consequences of invasive species establishment and spread in other river basins where dam mitigation is being considered.

\subsection{Can connectivity for native migratory fishes be improved despite ongoing fish invasions?}

Results of this study demonstrate the complexity and high costs associated with enhancing connectivity for native migratory species while simultaneously preventing dispersal and establishment of invasive fishes. Nonetheless, we identified dams that could be targeted for mitigation and still limit invasive species dispersal. In particular, dams that were repeatedly selected for mitigation irrespective of differences in budget, passabilities, and invasive species distributions were identified and mapped. In many cases, these included dams in upper tributaries of the Mississippi River above the current distribution of invasive bigheaded carps, however they also included some dams where selective mitigation (i.e., lift-and-sort fish passage) could be used to increase connectivity along the UMR mainstem and its tributaries where bigheaded carps presently occur. These results indicate the value of reestablishing connectivity to major tributaries of the UMR and are supported by studies demonstrating the importance of tributaries in maintaining fish biodiversity within large river systems (Pracheil et al., 2013). This habitat connectivity is particularly important for migratory fishes, which often 
require access to habitat not only along river mainstems but also their tributaries, which provide important areas for recruitment (Pracheil et al., 2009; Spurgeon et al., 2018) and can provide important conservation targets for restoring habitat connectivity (Pracheil et al., 2019).

In this study we included lift-and-sort fish passage structures as an option for dams that would limit dispersal and spread of invasive bigheaded carps, including at lock and dam locations (Wilcox et al., 2004). Lift-and-sort fish passages are expensive to build, require human labor to identify and sort fishes, and are operated only at certain times. This can make them less efficient compared to traditional fishways, particularly when a series of dams is involved (Nieminen et al., 2017). However, for a smaller subset of dams, lift-and-sort passage structures may be a feasible option for selective passage of native species in areas where bigheaded carp are present and there is a need to prevent their upstream advancement (Wilcox et al., 2004). In particular, Mississippi Lock and Dam 3, 18, and 19 were identified in the 'invasive' scenario runs as being locations with potential for selective habitat connectivity gains for the native migratory species despite higher economic costs and lower passabilities compared to traditional fishways. Since Lock and Dam 19 is a high-head dam with low baseline passability rates (Tripp et al., 2014), it has been viewed as a "pinch point" in limiting bigheaded carp dispersal in the UMR (Fritts et al., 2020) and may also provide an opportunity to selectively pass native species as indicated by results in this study. Aside from lift-and-sort structures, the need to restore connectivity for desirable species while restricting bigheaded carps has spurred various strategies within the UMR, including a combination of deterrence strategies (e.g., electric currents, bubbles, and noise) and modifications to gate and lock operation. Future prioritization work could evaluate these and other alternatives, however, they are unlikely to be completely effective at limiting invasive species passage (Rahel and McLaughlin, 2018). Zielinski et al. (2020) 
suggest an innovative method of selectively passing desirable fish species modeled on singlestream material recycling, where multiple sorting technologies are used to separate fish based on their physical characteristics. While some of these potential solutions are still in testing and development, they could represent future options for selective fish passage within the UMR and other river basins where selective barrier mitigations are needed.

\subsection{Coupling species distribution models with dam mitigation prioritizations}

By integrating predicted suitable habitat length and dam fragmentation data, this study demonstrates the benefits of utilizing SDMs in barrier prioritizations. Although numerous measures have been generated to quantify stream connectivity in barrier prioritizations (King and O’Hanley, 2016; McKay et al., 2017), few approaches explicitly incorporate habitat suitability for individual species, instead relying upon either structural connectivity measures (e.g., total stream length) or coarse surrogates of species habitat usage (e.g., species ranges; Fitzpatrick et al., 2021). Such approaches assume (either explicitly or implicitly) that all river reaches are equally suitable or are of equal quality, very likely leading to suboptimal solutions that overestimate habitat availability for target species. By utilizing SDMs in this study as well as weightings for multiple species based on imperilment status, our approach is likely to promote better efficiency over approaches where each species is considered independently (Milt et al., 2018). Nevertheless, the choice of relative weightings for species can alter fish passage project selection and tradeoffs among beneficiary species (Neeson et al., 2018).

A further benefit of using SDMs is the ability to incorporate other (non-dam) stressors in model development, as habitat restoration projects are at risk of failure if the full scope of human-induced changes to riverine landscapes are not considered (Bond and Lake, 2003, Palmer et al., 2005, Bernhardt and Palmer, 2011). Barrier mitigation projects that fail to consider habitat 
suitability can encourage the use of poorer quality habitats among individuals, reducing overall species fitness (i.e., "ecological traps"; McLaughlin et al., 2013). Previous barrier prioritizations have included non-barrier forms of human disturbance such as water quality conditions, imperviousness, and land use within watersheds (e.g., Hoenke et al., 2014; Diebel et al., 2015), which offer a means of targeting the reconnection of higher quality stream habitats. Including multiple forms of human disturbance to river networks (e.g., agriculture, urbanization, point source pollutant locations, etc.) as predictors in SDMs could aid in achieving restoration objectives involving dam mitigation actions by accounting for these species-habitat relationships and ensuring that suitable or higher quality habitats are represented, making them ideal for inclusion in species-based prioritizations.

\subsection{Study limitations}

Efficacy of fish passage structures has primarily been studied for Salmoniformes and Clupeiformes (Bunt et al., 2012; Noonan et al., 2012), with the range of fish passability values for traditional fishways and lift-and-sort structures from these studies being used as the basis for the low, moderate, and high passability estimates used in this study. However, far less is known about fish passage rates at fish passage structures for large-bodied species such as sturgeon (Jager et al., 2016). For lock and dam structures, annual average length of time gates were open was used as a surrogate for baseline pre-passability values, however gate operation (i.e., degree of openness) can vary both annually and seasonally with discharge conditions (Tripp et al., 2014; Bouska et al., 2019), leading to differing potential passabilities based on these factors. Further, fish passage can occur through locks during their operation (Fritts et al., 2020), including low levels of fish movement during closed gate conditions (Finger et al., 2020). We recognize that passability at dams can vary depending upon a number of factors, such as species-specific 
swimming capabilities, life stage, direction of movement (i.e., upstream or downstream) and physical characteristics of individual dams (Ioannidou and O’Hanley, 2019). For instance, previous research on large-bodied migratory species in the Mississippi River suggests that downstream passability at dams can be much greater than upstream passability (Tripp et al., 2014). Passability estimates are often a critical aspect of dam prioritizations, and a determination of how passability will be defined and how uncertainty in passability will be handled is key (Kemp and O'Hanley, 2010; McKay et al., 2013). Gathering this passability information may require extensive additional work (Bourne et al., 2011), such as use of field measurements (e.g., Diebel et al., 2015) or the development of predictive statistical models (e.g., JanuchowskiHartley et al., 2014). Such information would help inform passability estimates used in this and other dam prioritization studies and is an area of need in the evaluation of species-specific fish passage mitigation projects.

Dam and stream attributes were used in this study to develop both dam removal and fishway construction cost models. We acknowledge that estimates for dam removal or fishway construction based on models such as those developed in this study may be imprecise, particularly given the wide variety of conditions that may exist among dam locations. Actual dam removal and fishway construction costs often vary based on site specific characteristics, degree of contamination cleanup, and regional project cost differences. Some of these factors can be unforeseen even after site-specific feasibility assessments have been conducted in view of geological conditions (e.g., extensive subsurface bedrock) or culturally significant findings that require modified project plans. Many of the fishways with cost information used in our fishway cost model were designed for species such as alewife (Alosa pseudoharengus), blueback herring (Alosa aestivalis), and American shad (Alosa sapidissima). For larger-bodied species such as 
lake sturgeon, shovelnose sturgeon, and paddlefish, fishway construction costs are likely to be higher to meet fish passage needs for these species. Further, differences in fishway design (e.g., technical vs. nature-like) could account for differences in overall implementation costs and are not accounted for in the current study. Nonetheless, the models developed in this study rely on intuitive predictors, such as dam height, construction type, and age that have been successfully utilized in dam removal cost models in other studies (Zheng et al., 2009; Neeson et al., 2015). We also recognize that unmapped in-stream structures (e.g., road culverts in many regions) may also block fish movements in smaller channels; our modeling approach could be extended to account for these structures as spatial data on their locations improves (Fitzpatrick and Neeson, 2018).

\subsection{Conclusion}

Invasive fishes represent a pervasive threat to native fish globally, requiring approaches that foster native fish conservation while simultaneously managing for invasive fishes. Access to information at multiple spatial scales is increasingly acknowledged as being critical for making management decisions across large regions, including assessing the effectiveness of barrier mitigation to achieve management objectives given limited resources (Januchowski-Hartley et al., 2014, King and O’Hanley, 2016). Using information derived in this study, potential mitigation actions (i.e., dam removal and fish passage construction) for hundreds of dams was evaluated at a very large spatial extent. This approach can be replicated in other regions facing similar stream habitat connectivity dilemmas, including regions where dam building is occurring to meet increasing water supply and energy needs, helping managers and other stakeholders better understand the socioeconomic and ecological benefit/cost tradeoffs associated with dam mitigation in riverine landscapes facing ongoing species invasions. 


\section{ACKNOWLEDGEMENTS}

Funding and in-kind support for this study were provided by the Michigan Department of Natural Resources (ARC), USGS Aquatic Gap Program (HY), and Michigan State University AgBioResearch (DMI and KJB). We thank Kristen Bouska for providing longitudinal connectivity data for lock and dam structures on the Upper Mississippi and Illinois Rivers, Jared Ross for data assistance, and Brett Towler for discussions regarding fishways. 


\section{REFERENCES}

[dataset] American Rivers. (2020). American Rivers Dam Removal Database. Available: https://figshare.com/articles/dataset/American_Rivers_Dam_Removal_Database/5234068. Accessed: 8/6/2020.

Anderson, M., Olivero Sheldon, A., Apse, C., Bowden, A. A., Barnett, A. R., Beaty, B., Burns, C. Crabtree, D., Bechtel, D., Higgins, J., Royte, J., Dunscomb, J., \& Marangelo, P. (2013). Assessing Freshwater Ecosystems for their Resilience to Climate Change. The Nature Conservancy, Eastern North America Division.

https://www.conservationgateway.org/ConservationByGeography/NorthAmerica/UnitedStates/ edc/Documents/ED_freshwater_resilience_FWresilience2013.docx

Baguette, M., Blanchet, S., Legrand, D., Stevens, V. M., \& Turlure, C. (2013). Individual dispersal, landscape connectivity and ecological networks. Biological Reviews, 88, 310-326. https://doi.org/10.1111/brv.12000.

Bernhardt, E. S., \& Palmer, M. A. (2011). River restoration: the fuzzy logic of repairing reaches to reverse catchment scale degradation. Ecological Applications, 21, 1926-1931. https://doi.org/10.1890/10-1574.1.

Bond, N. R., \& Lake, P. S. (2003). Local habitat restoration in streams: constraints on the effectiveness of restoration for stream biota. Ecological Management \& Restoration, 4, 193198. https://doi.org/10.1046/j.1442-8903.2003.00156.x.

Bourne, C. M., Kehler, D. G., Wiersma, Y. F., \& Cote, D. (2011). Barriers to fish passage and barriers to fish passage assessments: the impact of assessment methods and assumptions on barrier identification and quantification of watershed connectivity. Aquatic Ecology, 45, 389403. https://doi.org/10.1007/s10452-011-9362-z.

Bouska, K. L., Houser, J. N., De Jager, N. R., \& Hendrickson, J. (2018). Developing a shared understanding of the Upper Mississippi River. Ecology and Society, 23, 6. https://doi.org/10.5751/ES-10014-230206.

Bouska, K. L., Houser, J. N., De Jager, N. R., Van Appledorn, M., \& Rogala, J. T. (2019). Applying concepts of general resilience to large river ecosystems: A case study from the Upper Mississippi and Illinois rivers. Ecological Indicators, 101, 1094-1110. https://doi.org/10.1016/j.ecolind.2019.02.002.

Bouska, K. (2020). Regime change in a large-floodplain river ecosystem: patterns in body-size and functional biomass indicate a shift in fish communities. Biological Invasions, 22, 33713389. https://doi.org/10.1007/s10530-020-02330-5.

Branco, P., Segurado, P., Santos, J. M., \& Ferreira, M. T. (2014). Prioritizing barrier removal to improve functional connectivity of rivers. Journal of Applied Ecology, 51, 1197-1206. https://doi.org/10.1111/1365-2664.12317.

Bunt, C. M., \& Cooke, S. J. (2001). Post-spawn movements and habitat use by greater redhorse, Moxostoma valenciennesi. Ecology of Freshwater Fish, 10, 57-60.

https://doi.org/10.1111/j.1600-0633.2001.tb00194.x. 
Bunt, C. M., Castro-Santos, T., \& Haro, A. (2012). Performance of fish passage structures at upstream barriers to migration. River Research and Applications, 28, 457-478.

https://doi.org/10.1002/rra.1565.

Campbell Grant, E. H., Lowe, W. H., \& Fagan, W. F. (2007). Living in the branches: population dynamics and ecological processes in dendritic networks. Ecology Letters, 10, 165-175. https://doi.org/10.1111/j.1461-0248.2006.01007.x.

Chick, J. H., Gibson-Reinemer, D. K., Soeken-Gittinger, L., \& Casper, A. F. (2020). Invasive silver carp is empirically linked to declines of native sport fish in the Upper Mississippi River System. Biological Invasions, 22, 723-734. https://doi.org/10.1007/s10530-019-02124-4.

Cooke, S. J., Bunt, C. M., Hamilton, S. J., Jennings, C. A., Pearson, M. P., Cooperman, M. S., \& Markle, D. F. (2005). Threats, conservation strategies, and prognosis for suckers (Catostomidae) in North America: insights from regional case studies of a diverse family of non-game fishes. Biological Conservation, 121, 317-331. https://doi.org/10.1016/j.biocon.2004.05.015.

Cooke, S. J., Paukert, C., \& Hogan, Z. (2012). Endangered river fish: factors hindering conservation and restoration. Endangered Species Research, 17, 179-191. https://doi.org/10.3354/esr00426.

Cooper, A. R., Infante, D. M., Daniel, W. M., Wehrly, K. E., Wang, L., \& Brenden, T. O. (2017). Assessment of dam effects on streams and fish assemblages of the conterminous USA. Science of the Total Environment, 586, 879-889. https://doi.org/10.1016/j.scitotenv.2017.02.067.

Cooper, A. R., Tsang, Y., Infante, D. M., Daniel, W. M., McKerrow, A. J., \& Wieferich, D. (2019). Protected areas lacking for many common fluvial fishes of the conterminous USA. Diversity and Distributions, 25, 1289-1303. https://doi.org/10.1111/ddi.12937.

Crook, D. A., Lowe, W. H., Allendorf, F. W., Erős, T., Finn, D. S., Gillanders, B. M., Hadwen, W. L., Harrod, C., Hermoso, V., Jennings, S., Kilada, R. W., Nagelkerken, I., Hansen, M. M., Page, T. J., Riginos, C., Fry, B., \& Hughes, J. M. (2015). Human effects on ecological connectivity in aquatic ecosystems: integrating scientific approaches to support management and mitigation. Science of the Total Environment, 534, 52-64. https://doi.org/10.1016/j.scitotenv.2015.04.034.

Daniel, W. M., Cooper, A. R., Badra, P. J., \& Infante, D. M. (2018). Predicting habitat suitability for eleven imperiled fluvial freshwater mussels. Hydrobiologia, 809, 265-283. https://doi.org/10.1007/s10750-017-3473-z.

De Jager, N. R., \& Houser, J. N. (2016). Patchiness in a large floodplain river: associations among hydrology, nutrients, and fish communities. River Research and Applications, 32, 1915-1926. https://doi.org/10.1002/rra.3026.

DeGrandchamp, K. L., Garvey, J. E., \& Colombo, R. E. (2008). Movement and habitat selection by invasive Asian carps in a large river. Transactions of the American Fisheries Society, 137, 45-56. https://doi.org/10.1577/T06-116.1. 
Diebel, M. W., Fedora, M., Cogswell, S., \& O'Hanley, J. R. (2015). Effects of road crossings on habitat connectivity for stream-resident fish. River Research and Applications, 31, 1251-1261. https://doi.org/10.1002/rra.2822.

Elith, J., Leathwick, J. R., \& Hastie, T. (2008). A working guide to boosted regression trees. Journal of Animal Ecology, 77, 802-813. https://doi.org/10.1111/j.13652656.2008.01390.x.

Erős, T., O'Hanley, J. R., \& Czeglédi, I. (2018). A unified model for optimizing riverscape conservation. Journal of Applied Ecology, 55, 1871-1883. https://doi.org/10.1111/13652664.13142.

Fagan, W. F. (2002). Connectivity, fragmentation, and extinction risk in dendritic metapopulations. Ecology, 83, 3243-3249. https://doi.org/10.1890/00129658(2002)083[3243:CFAERI]2.0.CO;2.

Finger, J. S., Riesgraf, A. T., Zielinski, D. P., \& Sorensen, P. W. (2020). Monitoring upstream fish passage through a Mississippi River lock and dam reveals species differences in lock chamber usage and supports a fish passage model which describes velocity-dependent passage through spillway gates. River Research and Applications, 36, 36-46. https://doi.org/10.1002/rra.3530.

Fitzpatrick, K. B., \& Neeson, T. M. (2018). Aligning dam removals and road culvert upgrades boosts conservation return-on-investment. Ecological Modelling, 368, 198-204. https://doi.org/10.1016/i.ecolmodel.2017.11.018.

Fitzpatrick, K. B., Moody, A. T., Milt, A., Herbert, M. E., Khoury, M., Yacobson, E., Ross, J. A., Doran, P. J., Ferris, M. C., McIntyre, P. B., \& Neeson, T. M. (2020). Can indicator species guide conservation investments to restore connectivity in Great Lakes tributaries? Biodiversity and Conservation, 30, 165-182. https://doi.org/10.1007/s10531-020-02084-5.

Fritts, A. K., Knights, B. C., Stanton, J. C., Milde, A. S., Vallazza, J. M., Brey, M. K., Tripp, S. J., Devine, T. E., Sleeper, W., Lamer, J. T., \& Mosel, K. J. (2020). Lock operations influence upstream passages of invasive and native fishes at a Mississippi River high-head dam. Biological Invasions, 1-24. https://doi.org/10.1007/s10530-020-02401-7.

Galat, D. L., \& Zweimüller, I. (2001). Conserving large-river fishes: is the highway analogy an appropriate paradigm? Journal of the North American Benthological Society, 20, 266-279. https://doi.org/10.2307/1468321.

Garvey, J., Ickes, B., \& Zigler, S. (2010). Challenges in merging fisheries research and management: the Upper Mississippi River experience. Hydrobiologia, 640, 125-144. https://doi.org/10.1007/s10750-009-0061-X.

[dataset] GBIF. (2020a). GBIF occurrence download (Acipenser fulvescens). Available: https://doi.org/10.15468/dl.dtwq84. Accessed: 10/9/2020.

[dataset] GBIF. (2020b). GBIF occurrence download (Polyodon spathula). Available: https://doi.org/10.15468/dl.jnykwf. Accessed: 10/9/2020. 
Guisan, A., Edwards, T. C., \& Hastie, T. (2002). Generalized linear and generalized additive models in studies of species distributions: setting the scene. Ecological Modelling, 157, 89100. https://doi.org/10.1016/S0304-3800(02)00204-1.

Hanski, I. (1999). Habitat connectivity, habitat continuity, and metapopulations in dynamic landscapes. Oikos 87, 209-219. https://doi.org/10.2307/3546736.

Hastie, T. J., \& Tibshirani, R. J. (1986). Generalized additive models. Statistical Science, 1, 297318. https://doi.org/10.1214/ss/1177013604.

Hoenke, K. M., Kumar, M., \& Batt, L. (2014). A GIS based approach for prioritizing dams for potential removal. Ecological Engineering, 64, 27-36.

https://doi.org/10.1016/j.ecoleng.2013.12.009.

Hupfeld, R. N., Phelps, Q. E., Tripp, S. J., \& Herzog, D. P. (2016). Mississippi River basin paddlefish population dynamics: implications for the management of a highly migratory species. Fisheries, 41, 600-610. https://doi.org/10.1080/03632415.2016.1221701.

IBM (2020). IBM ILOG CPLEX Optimization Studio v12.10. Available: https://www.ibm.com/products/ilog-cplex-optimization-studio (downloaded 9/11/2020).

Ioannidou, C., \& O’Hanley, J. R. (2019). The importance of spatiotemporal fish population dynamics in barrier mitigation planning. Biological Conservation, 231, 67-76. https://doi.org/10.1016/j.biocon.2019.01.001.

Jager, H. I., Parsley, M. J., Cech, J. J., McLaughlin, R. L., Forsythe, P. S., Elliott, R. F., \& Pracheil, B. M. (2016). Reconnecting fragmented sturgeon populations in North American rivers. Fisheries, 41, 140-148. https://doi.org/10.1080/03632415.2015.1132705.

Januchowski-Hartley, S. R., Diebel, M., Doran, P. J., \& McIntyre, P. B. (2014). Predicting road culvert passability for migratory fishes. Diversity and Distributions, 20, 1414-1424. https://doi.org/10.1111/ddi.12248.

Kemp, P. S., \& O'Hanley, J. R. (2010). Procedures for evaluating and prioritising the removal of fish passage barriers: a synthesis. Fisheries Management and Ecology, 17, 297-322. https://doi.org/10.1111/j.1365-2400.2010.00751.x.

Kerr, J. R., Vowles, A. S., Crabb, M. C., \& Kemp, P. S. (2021). Selective fish passage: restoring habitat connectivity without facilitating the spread of a non-native species. Journal of Environmental Management, 110908. https://doi.org/10.1016/j.jenvman.2020.110908.

King, S., \& O'Hanley, J. R. (2016). Optimal fish passage barrier removal-revisited. River Research and Applications, 32, 418-428. https://doi.org/10.1002/rra.2859.

King, S., O'Hanley, J. R., \& Fraser, I. (2021). How to choose? A bioeconomic model for optimizing river barrier mitigation actions. Ecological Economics, 181, 106892. https://doi.org/10.1016/j.ecolecon.2020.106892.

Kinlock, N. L., Laybourn, A. J., Murphy, C. E., Hoover, J. J., \& Friedenberg, N. A. (2020). Modelling bioenergetic and population-level impacts of invasive bigheaded carps (Hypophthalmichthys spp.) on native paddlefish (Polyodon spathula) in backwaters of the 
lower Mississippi River. Freshwater Biology, 65, 1086-1100.

https://doi.org/10.1111/fwb.13494.

Klein, Z. B., Quist, M. C., Miranda, L. E., Marron, M. M., Steuck, M. J., \& Hansen, K. A. (2018). Commercial fisheries of the upper Mississippi River: a century of sustained harvest. Fisheries, 43, 563-574. https://doi.org/10.1002/fsh.10176.

Kocovsky, P. M., Ross, R. M., \& Dropkin, D. S. (2009). Prioritizing removal of dams for passage of diadromous fishes on a major river system. River Research and Applications, 25, 107-117. https://doi.org/10.1002/rra.1094.

Larson, J. H., Knights, B. C., McCalla, S. G., Monroe, E., Tuttle-Lau, M., Chapman, D. C., George, A. E., Vallazza, J. M., \& Amberg, J. (2017). Evidence of Asian carp spawning upstream of a key choke point in the Mississippi River. North American Journal of Fisheries Management, 37, 903-919. https://doi.org/10.1080/02755947.2017.1327901.

Lavis, D. S., Hallett, A., Koon, E. M., \& McAuley, T. C. (2003). History of and advances in barriers as an alternative method to suppress sea lampreys in the Great Lakes. Journal of Great Lakes Research, 29, 362-372. https://doi.org/10.1016/S0380-1330(03)70500-0.

Liermann, C. R., Nilsson, C., Robertson, J., \& Ng, R. Y. (2012). Implications of dam obstruction for global freshwater fish diversity. BioScience, 62, 539-548. https://doi.org/10.1525/bio.2012.62.6.5.

Lin, H. Y., Robinson, K., Milt, A., \& Walter, L. (2019). The application of decision support tools and the influence of local data in prioritizing barrier removal in lower Michigan, USA. Journal of Great Lakes Research, 45, 360-370. https://doi.org/10.1016/j.jglr.2019.01.008.

Liu, C., Berry, P. M., Dawson, T. P., \& Pearson, R. G. (2005). Selecting thresholds of occurrence in the prediction of species distributions. Ecography, 28, 385-393. https://doi.org/10.1111/j.0906-7590.2005.03957.x.

Lucas, M., \& Baras, E. (2001). Migration of freshwater fishes. Blackwell Science. https://doi.org/10.1002/9780470999653.

Lyons, J., Zorn, T., Stewart, J., Seelbach, P., Wehrly, K., \& Wang, L. (2009). Defining and characterizing coolwater streams and their fish assemblages in Michigan and Wisconsin, USA. North American Journal of Fisheries Management, 29, 1130-1151. https://doi.org/10.1577/M08-118.1.

McKay, S. K., Schramski, J. R., Conyngham, J. N., \& Fischenich, J. C. (2013). Assessing upstream fish passage connectivity with network analysis. Ecological Applications, 23, 13961409. https://doi.org/10.1890/12-1564.1.

McKay, S. K., Cooper, A. R., Diebel, M. W., Elkins, D., Oldford, G., Roghair, C., \& Wieferich, D. (2017). Informing watershed connectivity barrier prioritization decisions: a synthesis. River Research and Applications, 33, 847-862. https://doi.org/10.1002/rra.3021.

McLaughlin, R. L., Smyth, E. R., Castro-Santos, T., Jones, M. L., Koops, M. A., Pratt, T. C., \& Vélez-Espino, L. A. (2013). Unintended consequences and trade-offs of fish passage. Fish and Fisheries, 14, 580-604. https://doi.org/10.1111/faf.12003. 
McManamay, R. A., Perkin, J. S., \& Jager, H. I. (2019). Commonalities in stream connectivity restoration alternatives: an attempt to simplify barrier removal optimization. Ecosphere, 10, e02596. https://doi.org/10.1002/ecs2.2596.

Milt, A. W., Doran, P. J., Ferris, M. C., Moody, A. T., Neeson, T. M., \& McIntyre, P. B. (2017). Local-scale benefits of river connectivity restoration planning beyond jurisdictional boundaries. River Research and Applications, 33, 788-795. https://doi.org/10.1002/rra.3135.

Milt, A. W., Diebel, M. W., Doran, P. J., Ferris, M. C., Herbert, M., Khoury, M. L., Moody, A. T., Neeson, T. M., Ross, J., Treska, T., O’Hanley, J. R., Walter, L., Wangen, S. R., Yacobson, E., \& McIntyre, P. B. (2018). Minimizing opportunity costs to aquatic connectivity restoration while controlling an invasive species. Conservation Biology, 32, 894-904. https://doi.org/10.1111/cobi.13105.

[dataset] MTFWP. (2020). Montana Fish, Wildlife \& Parks Fish Survey Locations. Available: https://gis-mtfwp.opendata.arcgis.com/datasets/a154da2436c74a7c8cea457988147862_0.

Accessed: 10/9/2020.

Neely, B. C., Pegg, M. A., \& Mestl, G. E. (2009). Seasonal use distributions and migrations of blue sucker in the Middle Missouri River. Ecology of Freshwater Fish, 18, 437-444. https://doi.org/10.1111/j.1600-0633.2009.00360.x.

Neeson, T. M., Ferris, M. C., Diebel, M. W., Doran, P. J., O’Hanley, J. R., \& McIntyre, P. B. (2015). Enhancing ecosystem restoration efficiency through spatial and temporal coordination. Proceedings of the National Academy of Sciences, 112, 6236-6241. https://doi.org/10.1073/pnas.1423812112.

Neeson, T. M., Doran, P. J., Ferris, M. C., Fitzpatrick, K. B., Herbert, M., Khoury, M., Moody, A. T., Ross, J., Yacobson, E., \& McIntyre, P. B. (2018). Conserving rare species can have high opportunity costs for common species. Global Change Biology, 24, 3862-3872. https://doi.org/10.1111/gcb.14162.

Nieminen, E., Hyytiäinen, K., \& Lindroos, M. (2017). Economic and policy considerations regarding hydropower and migratory fish. Fish and Fisheries, 18, 54-78. https://doi.org/10.1111/faf.12167.

Nilsson, C., Reidy, C. A., Dynesius, M., \& Revenga, C. (2005). Fragmentation and flow regulation of the world's large river systems. Science, 308, 405-408. https://doi.org/10.1126/science.1107887.

Noonan, M. J., Grant, J. W., \& Jackson, C. D. (2012). A quantitative assessment of fish passage efficiency. Fish and Fisheries, 13, 450-464. https://doi.org/10.1111/j.1467-2979.2011.00445.x.

O'Connor, J. E., Duda, J. J., \& Grant, G. E. (2015). 1000 dams down and counting. Science, 348, 496-497. https://doi.org/10.1126/science.aaa9204.

O'Hanley, J. R., Pompeu, P. S., Louzada, M., Zambaldi, L. P., \& Kemp, P. S. (2020). Optimizing hydropower dam location and removal in the São Francisco river basin, Brazil to balance hydropower and river biodiversity tradeoffs. Landscape and Urban Planning, 195, 103725. https://doi.org/10.1016/j.landurbplan.2019.103725. 
[dataset] Ostroff, A., Wieferich, D., Cooper, A., \& Infante, D. (2013). 2012 National Anthropogenic Barrier Dataset (NABD). National Fish Habitat Partnership Data System. Available: https://www.sciencebase.gov/catalog/item/512cf142e4b0855fde669828. Accessed 03/01/2013.

Palmer, M. A., Bernhardt, E. S., Allan, J. D., Lake, P. S., Alexander, G., Brooks, S., Carr, J., Clayton, S., Dahm, C. N., Follstad Shah, J., Galat, D. L., Loss, S. G., Goodwin, P., Hart, D. D., Hassett, B., Jenkinson, R., Kondolf, G. M., Lave, R., Meyer, J. L., O’Donnell, T. K., Pagano, L., \& Sudduth, E. (2005). Standards for ecologically successful river restoration. Journal of Applied Ecology, 42, 208-217. https://doi.org/10.1111/j.1365-2664.2005.01004.x.

Phillips, S. J., Anderson, R. P., \& Schapire, R. E. (2006). Maximum entropy modeling of species geographic distributions. Ecological Modelling, 190, 231-259.

https://doi.org/10.1016/j.ecolmodel.2005.03.026.

Pompeu, P. S., Agostinho, A. A., \& Pelicice, F. M. (2012). Existing and future challenges: the concept of successful fish passage in South America. River Research and Applications, 28, 504-512. https://doi.org/10.1002/rra.1557.

Pracheil, B. M., Pegg, M. A., \& Mestl, G. E. (2009). Tributaries influence recruitment of fish in large rivers. Ecology of Freshwater Fish, 18, 603-609. https://doi.org/10.1111/j.16000633.2009.00376.x.

Pracheil, B. M., Pegg, M. A., Powell, L. A., \& Mestl, G. E. (2012). Swimways: protecting paddlefish through movement-centered management. Fisheries, 37, 449-457. https://doi.org/10.1080/03632415.2012.722877.

Pracheil, B. M., McIntyre, P. B., \& Lyons, J. D. (2013). Enhancing conservation of large-river biodiversity by accounting for tributaries. Frontiers in Ecology and the Environment, 11, 124128. https://doi.org/10.1890/120179.

Pracheil, B. M., Lyons, J., Hamann, E. J., Short, P. H., \& McIntyre, P. B. (2019). Lifelong population connectivity between large rivers and their tributaries: a case study of shovelnose sturgeon from the Mississippi and Wisconsin rivers. Ecology of Freshwater Fish, 28, 20-32. https://doi.org/10.1111/eff.12423.

Rahel, F. J. (2013). Intentional fragmentation as a management strategy in aquatic systems. BioScience, 63, 362-372. https://doi.org/10.1525/bio.2013.63.5.9.

Rahel, F. J., \& McLaughlin, R. L. (2018). Selective fragmentation and the management of fish movement across anthropogenic barriers. Ecological Applications, 28, 2066-2081. https://doi.org/10.1002/eap.1795.

Reid, S. M. (2006). Timing and demographic characteristics of redhorse spawning runs in three Great Lakes basin rivers. Journal of Freshwater Ecology, 21, 249-258. https://doi.org/10.1080/02705060.2006.9664993.

Rodeles, A. A., Galicia, D., \& Miranda, R. (2020). A new method to include fish biodiversity in river connectivity indices with applications in dam impact assessments. Ecological Indicators, 117, 106605. https://doi.org/10.1016/j.ecolind.2020.106605.

Schlosser, I.J., \& Angermeier, P.L., 1995. Spatial variation in demographic processes of lotic 
fishes: conceptual models, empirical evidence, and implications for conservation. Am. Fish. Soc. Symp. 17, 392-401.

Sethi, S. A., O’Hanley, J. R., Gerken, J., Ashline, J., \& Bradley, C. (2017). High value of ecological information for river connectivity restoration. Landscape Ecology, 32, 2327-2336. https://doi.org/10.1007/s10980-017-0571-2.

Silva, A. T., Lucas, M. C., Castro-Santos, T., Katopodis, C., Baumgartner, L. J., Thiem, J. D., Aarestrup, K., Pompeu, P. S., O’Brien, G. C., Braun, D. C., Burnett, N. J., Zhu, D. Z.,

Fjeldstad, H., Forseth, T., Rajaratnam, N., Williams, J. G., \& Cooke, S. J. (2018). The future of fish passage science, engineering, and practice. Fish and Fisheries, 19, 340-362. https://doi.org/10.1111/faf.12258.

Snyder, C. (2019). A microchemical analysis of native fish passage through Brandon Road Lock and Dam, Des Plaines River, Illinois (Master's thesis). Southern Illinois University Carbondale. https://opensiuc.lib.siu.edu/theses/2601/.

Spurgeon, J. J., Pegg, M. A., Hamel, M. J., \& Steffensen, K. D. (2018). Spatial structure of largeriver fish populations across main-stem and tributary habitats. River Research and Applications, 34, 807-815. https://doi.org/10.1002/rra.3289.

Swets, J. A. (1988). Measuring the accuracy of diagnostic systems. Science, 240, 1285-1293. https://doi.org/10.1126/science.3287615.

Taylor, A. T., Papeş, M., \& Long, J. M. (2018). Incorporating fragmentation and non-native species into distribution models to inform fluvial fish conservation. Conservation Biology, 32, 171-182. https://doi.org/10.1111/cobi.13024.

Tripp, S., Brooks, R., Herzog, D., \& Garvey, J. (2014). Patterns of fish passage in the upper Mississippi River. River Research and Applications, 30, 1056-1064. https://doi.org/10.1002/rra.2696.

Tripp, S. J., Phelps, Q. E., Hupfeld, R. N., Herzog, D. P., Ostendorf, D. E., Moore, T. L., Brooks, R. C., \& Garvey, J. E. (2019). Sturgeon and paddlefish migration: evidence to support the need for interjurisdictional management. Fisheries, 44, 183-193. https://doi.org/10.1002/fsh.10215.

Turney, D. D. (2020). Hydrological and Lock Operation Conditions Associated with Pinch-Point Dam Passage by Paddlefish and Bigheaded Carp in the Upper Mississippi River (Master's thesis). Western Illinois University. https://search.proquest.com/openview/6e1e26076e00697d0e0a20da4be5c757/1?pqorigsite $=$ gscholar \&cbl $=44156$.

[dataset] U.S. Environmental Protection Agency and U.S. Geological Survey (USEPA and USGS). (2015). National Hydrography Dataset Plus V2 (NHDPlusV2). Available: https://www.epa.gov/waterdata/get-nhdplus-national-hydrography-dataset-plusdata\#v2datamap. Accessed 7/31/2015.

[dataset] U.S. Geological Survey (USGS). (2018). State Wildlife Action Plans (SWAP): A national look at Species of Greatest Conservation Need as reported in State Wildlife Action Plans. https://www1.usgs.gov/csas/swap/index.html. Accessed 9/6/2018. 
[dataset] U.S. Geological Survey (USGS). (2020a). USGS Nonindigenous Aquatic Species. Bighead Carp (Hypophthalmichthys nobilis) - Species Profile. Available: https://nas.er.usgs.gov/viewer/omap.aspx?SpeciesID=551. Accessed 10/31/2020.

[dataset] U.S. Geological Survey (USGS). (2020b). USGS Nonindigenous Aquatic Species. Silver Carp (Hypophthalmichthys molitrix) - Species Profile. Available: https://nas.er.usgs.gov/viewer/omap.aspx?SpeciesID=549. Accessed 10/31/2020.

Vélez-Espino, L. A., McLaughlin, R. L., Jones, M. L., \& Pratt, T. C. (2011). Demographic analysis of trade-offs with deliberate fragmentation of streams: Control of invasive species versus protection of native species. Biological Conservation, 144, 1068-1080. https://doi.org/10.1016/j.biocon.2010.12.026.

Wang, L., Lyons, J., Kanehl, P., \& Bannerman, R. (2001). Impacts of urbanization on stream habitat and fish across multiple spatial scales. Environmental Management, 28, 255-266. https://doi.org/10.1007/s0026702409.

Wang, L., Infante, D., Esselman, P., Cooper, A., Wu, D., Taylor, W., Beard, D., Whelan, G., \& Ostroff, A. (2011). A hierarchical spatial framework and database for the national river fish habitat condition assessment. Fisheries, 36, 436-449. https://doi.org/10.1080/03632415.2011.607075.

Wiens, J. A. (2002). Riverine landscapes: taking landscape ecology into the water. Freshwater Biology, 47, 501-515. https://doi.org/10.1046/j.1365-2427.2002.00887.x.

Wilcox, D. B., Stefanik, E. L., Kelner, D. E., Cornish, M. A., Johnson, D. J., Hodgins, I. J., Zigler, S. J., \& Johnson, B. L. (2004). Improving fish passage through navigation dams on the Upper Mississippi River System. ENV Report 54. U.S. Army Corps of Engineers.

Yu, H., Cooper, A. R., \& Infante, D. M. (2020). Improving species distribution model predictive accuracy using species abundance: application with boosted regression trees. Ecological Modelling, 432, 109202. https://doi.org/10.1016/j.ecolmodel.2020.109202.

Zheng, P. Q., Hobbs, B. F., \& Koonce, J. F. (2009). Optimizing multiple dam removals under multiple objectives: linking tributary habitat and the Lake Erie ecosystem. Water Resources Research, 45(12). https://doi.org/10.1029/2008WR007589.

Zielinski, D. P., McLaughlin, R. L., Pratt, T. C., Goodwin, R. A., \& Muir, A. M. (2020). SingleStream Recycling Inspires Selective Fish Passage Solutions for the Connectivity Conundrum in Aquatic Ecosystems. BioScience, 70, 871-886. https://doi.org/10.1093/biosci/biaa090. 
Table 1. Fish species names, number of presences used in species distribution modeling, and area under the receiver operating characteristic curve (AUC) based on 10-fold cross-validation. Abbreviations for U.S. states with 2015 Species of Greatest Conservation Need (SGCN) listings within the study region are also included.

\begin{tabular}{|c|c|c|c|c|}
\hline Family/species & Common name & Presences & AUC & $\begin{array}{c}\text { States with } \\
\text { SGCN listing }\end{array}$ \\
\hline \multicolumn{5}{|l|}{ Acipenseridae } \\
\hline Acipenser fulvescens & Lake sturgeon & 57 & 0.98 & $\begin{array}{c}\text { IA, IL, IN, MN, } \\
\text { MO, WI }\end{array}$ \\
\hline Scaphirhynchus platorynchus & Shovelnose sturgeon & 50 & 0.97 & $\mathrm{IA}, \mathrm{MO}, \mathrm{SD}$ \\
\hline \multicolumn{5}{|l|}{ Catostomidae } \\
\hline Cycleptus elongatus & Blue sucker & 150 & 0.98 & $\begin{array}{l}\text { IA, MN, MO, } \\
\text { WI, SD }\end{array}$ \\
\hline Moxostoma carinatum & River redhorse & 404 & 0.94 & IA, IL, MO, WI \\
\hline Moxostoma valenciennesi & Greater redhorse & 168 & 0.90 & $\mathrm{IL}, \mathrm{IN}$ \\
\hline \multicolumn{5}{|l|}{ Polyodontidae } \\
\hline Polyodon spathula & Paddlefish & 42 & 0.97 & $\begin{array}{l}\mathrm{IA}, \mathrm{IL}, \mathrm{MN} \\
\mathrm{MO}, \mathrm{WI}\end{array}$ \\
\hline
\end{tabular}

Table 2. Dam and stream attributes evaluated as predictors for dam removal and fishway construction cost models. Dam attributes were sourced from the National Anthropogenic Barrier Dataset (NABD), while stream attributes were obtained from the National Hydrography Dataset Plus Version 2 (NHDPlusV2).

\begin{tabular}{lll}
\hline Type/predictor & Description & Units \\
\hline Dam attributes & & \\
Dam height & Dam structural height & $\mathrm{m}$ \\
Dam length & Dam structural length & $\mathrm{m}$ \\
Reservoir storage & Reservoir storage volume under normal & $\mathrm{ha} / \mathrm{m}$ \\
& storage conditions & years \\
Age & Dam age & $\mathrm{n} / \mathrm{a}$ \\
Dam type & Dam construction type & $\mathrm{n} / \mathrm{a}$ \\
Owner type & Ownership type (private vs. public) & $\mathrm{n} / \mathrm{a}$ \\
Dam purpose & Main dam operation purpose & $\mathrm{n} / \mathrm{a}$ \\
Hazard & Hazard status for dam failure/breach & \\
Stream attributes & & $\mathrm{m} / \mathrm{s}$ \\
Stream discharge & Estimated mean annual stream discharge & (1971-2000) \\
Stream order & Strahler stream order & $\mathrm{n} / \mathrm{a}$ \\
Stream gradient & Slope of the stream reach & $\mathrm{m} / \mathrm{m}$ \\
\hline
\end{tabular}


Table 3. Total predicted habitat length within the study region for six native migratory fish species along with overall number of patches containing predicted habitat and those with $>25$, $>50$, and $>100$ river kilometers $(\mathrm{rkm})$ of predicted habitat length.

\begin{tabular}{lrrrrr}
\hline Common name & $\begin{array}{c}\text { Predicted } \\
\text { habitat } \\
\text { length (rkm) }\end{array}$ & $\begin{array}{l}\text { Total } \\
\text { patches }\end{array}$ & $\begin{array}{l}\text { Patches } \\
>25 \mathrm{rkm}\end{array}$ & $\begin{array}{l}\text { Patches } \\
>50 \mathrm{rkm}\end{array}$ & $\begin{array}{l}\text { Patches } \\
>100 \mathrm{rkm}\end{array}$ \\
\hline Paddlefish & 2766 & 46 & 28 & 18 & 9 \\
Lake sturgeon & 2753 & 72 & 27 & 14 & 7 \\
Shovelnose sturgeon & 3508 & 44 & 22 & 19 & 12 \\
Blue sucker & 3880 & 48 & 36 & 25 & 13 \\
River redhorse & 5283 & 92 & 51 & 32 & 16 \\
Greater redhorse & 8601 & 175 & 81 & 49 & 18 \\
\hline
\end{tabular}

Table 4. Estimated overlap in habitat length and number of patches containing habitat between six native migratory fish species and invasive bigheaded carps.

\begin{tabular}{lrrrr}
\hline Common name & $\begin{array}{c}\text { Habitat } \\
\text { overlap } \\
\text { (rkm) }\end{array}$ & $\begin{array}{c}\text { \% Habitat } \\
\text { overlap }\end{array}$ & $\begin{array}{c}\text { Patch } \\
\text { overlap }\end{array}$ & $\begin{array}{c}\text { \% Patch } \\
\text { overlap }\end{array}$ \\
\hline Paddlefish & 1744 & 63.1 & 29 & 63.0 \\
Lake sturgeon & 568 & 20.6 & 13 & 18.1 \\
Shovelnose sturgeon & 1937 & 55.2 & 25 & 56.8 \\
Blue sucker & 2604 & 67.1 & 37 & 77.1 \\
River redhorse & 1270 & 24.0 & 26 & 28.3 \\
Greater redhorse & 820 & 9.5 & 24 & 13.7 \\
\hline
\end{tabular}


Table 5. Comparison of costs and cost factors for combined habitat gain ranging from 10-50\% for the 'no invasives' and 'invasives' scenarios given high, moderate, and low post-mitigation passability levels. Cost factors are defined as the multiplicative cost increase between the 'no invasives' and 'invasives' scenarios for a given habitat gain and passability level. Note, habitat gains beyond 30\% are not achievable in the 'invasive' scenario with low passability and are unavailable for comparison.

\begin{tabular}{|c|c|c|c|c|c|c|c|c|c|}
\hline \multirow[b]{3}{*}{$\begin{array}{l}\text { Habitat } \\
\text { gain \% }\end{array}$} & \multicolumn{3}{|c|}{ High } & \multicolumn{3}{|c|}{ Moderate } & \multicolumn{3}{|c|}{ Low } \\
\hline & \multicolumn{2}{|c|}{ Cost (millions USD) } & \multirow[b]{2}{*}{$\begin{array}{l}\text { Cost } \\
\text { factor }\end{array}$} & \multicolumn{2}{|c|}{ Cost (millions USD) } & \multirow[b]{2}{*}{$\begin{array}{l}\text { Cost } \\
\text { factor }\end{array}$} & \multicolumn{2}{|c|}{ Cost (millions USD) } & \multirow[b]{2}{*}{$\begin{array}{l}\text { Cost } \\
\text { factor }\end{array}$} \\
\hline & $\begin{array}{c}\text { No } \\
\text { Invasives }\end{array}$ & Invasives & & $\begin{array}{c}\text { No } \\
\text { Invasives }\end{array}$ & Invasives & & $\begin{array}{c}\text { No } \\
\text { Invasives }\end{array}$ & Invasives & \\
\hline 10 & 3 & 8 & 2.7 & 6 & 15 & 2.5 & 11 & 31 & 2.8 \\
\hline 15 & 7 & 23 & 3.3 & 10 & 46 & 4.6 & 21 & 98 & 4.7 \\
\hline 20 & 9 & 46 & 5.1 & 15 & 71 & 4.7 & 42 & 173 & 4.1 \\
\hline 25 & 10 & 59 & 5.9 & 21 & 106 & 5.0 & 69 & 286 & 4.1 \\
\hline 30 & 13 & 74 & 5.7 & 33 & 132 & 4.0 & 107 & 445 & 4.2 \\
\hline 35 & 18 & 88 & 4.9 & 48 & 175 & 3.6 & 158 & $\mathrm{n} / \mathrm{a}$ & $\mathrm{n} / \mathrm{a}$ \\
\hline 40 & 22 & 99 & 4.5 & 55 & 217 & 3.9 & 238 & $\mathrm{n} / \mathrm{a}$ & $\mathrm{n} / \mathrm{a}$ \\
\hline 45 & 29 & 122 & 4.2 & 63 & 277 & 4.4 & 352 & $\mathrm{n} / \mathrm{a}$ & $\mathrm{n} / \mathrm{a}$ \\
\hline 50 & 37 & 139 & 3.8 & 77 & 322 & 4.2 & 470 & $\mathrm{n} / \mathrm{a}$ & $\mathrm{n} / \mathrm{a}$ \\
\hline
\end{tabular}




\section{FIGURE HEADINGS}

Figure 1. Map of the study region within the Upper Missippi River (UMR) showing 2,564 large dam locations, streams with an estimated mean annual discharge $\geq 1 \mathrm{~m}^{3} / \mathrm{s}$, and state boundaries. Patch catchments, representing subdivisions of the basin at large dam locations, are shown in inset (a) while the study basin (hatched area) is shown in relation to the broader Mississippi River basin boundary in inset (b).

Figure 2. Flow diagram of our study's approach to prioritize dam mitigation in order to compare 'no invasives' vs. 'invasives' scenarios for low, moderate, and high post-mitigation passability levels.

Figure 3. Predicted species distributions for paddlefish (a), lake sturgeon (b), shovelnose sturgeon (c), blue sucker (d), river redhorse (e), and greater redhorse (f) within their native ranges for the study basin.

Figure 4. Partial dependence plots of GAM models showing the marginal effects of predictors on predicted dam removal (a) and fishway construction (b) costs when all other predictors are held at their means. Solid lines represent mean responses, dashed lines represent $95 \%$ confidence intervals, and ticks along the $\mathrm{x}$-axis show predictor variable distributions. Estimated degrees of freedom are indicted in $y$-axis labels of smoothed variables.

Figure 5. Optimized cost-benefit curves of habitat gain versus budget for the 'no invasives' scenario (blue) and 'invasives' scenario (red) with individual lines corresponding to low (dotted), moderate (dashed), and high (solid) post-mitigation passability.

Figure 6. Species-specific cost-benefit curves for paddlefish (a), lake sturgeon (b), shovelnose sturgeon (c), blue sucker (d), river redhorse (e), and greater redhorse (f) showing habitat gain versus budget for the 'no invasives' scenario (blue) and 'invasives' scenario (red), with individual lines corresponding to low (dotted), moderate (dashed), and high (solid) postmitigation passability. Note, unlike with combined habitat gain (Figure 5), habitat gain for individual species does not necessarily monotonically increase with budget due to tradeoffs among species.

Figure 7. Maps showing the percentage of times a dam was selected for mitigation under the 'no invasives' (a) and 'invasives' (b) scenarios across budgets in the range \$1-500M USD. Note, results are pooled over the low, moderate, and high post-passability levels. Dams displayed represent only those reducing connectivity among predicted habitats for one or more species $(n=$ 240). 
[Figure 1]

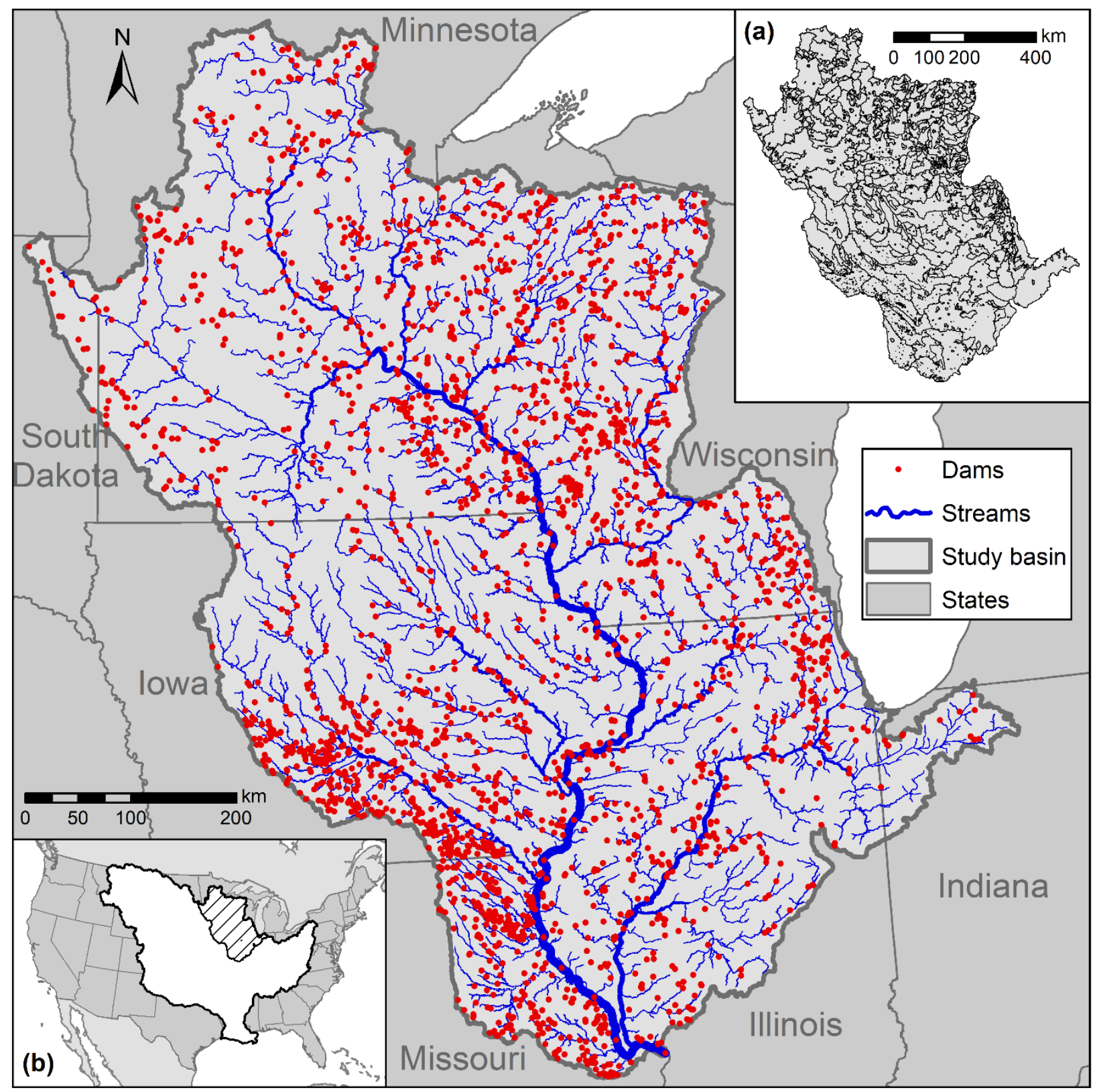


[Figure 2]

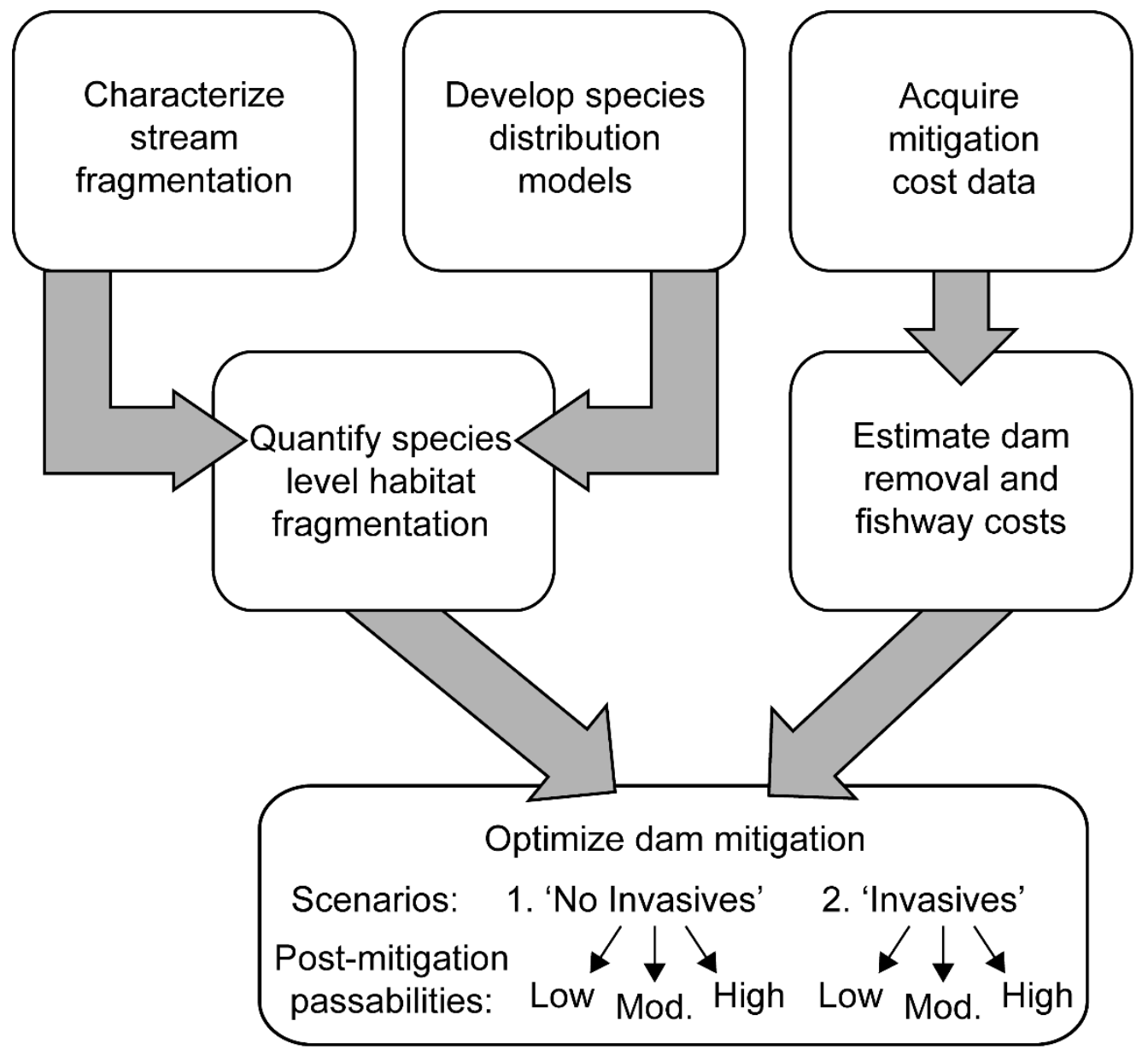


[Figure 3]
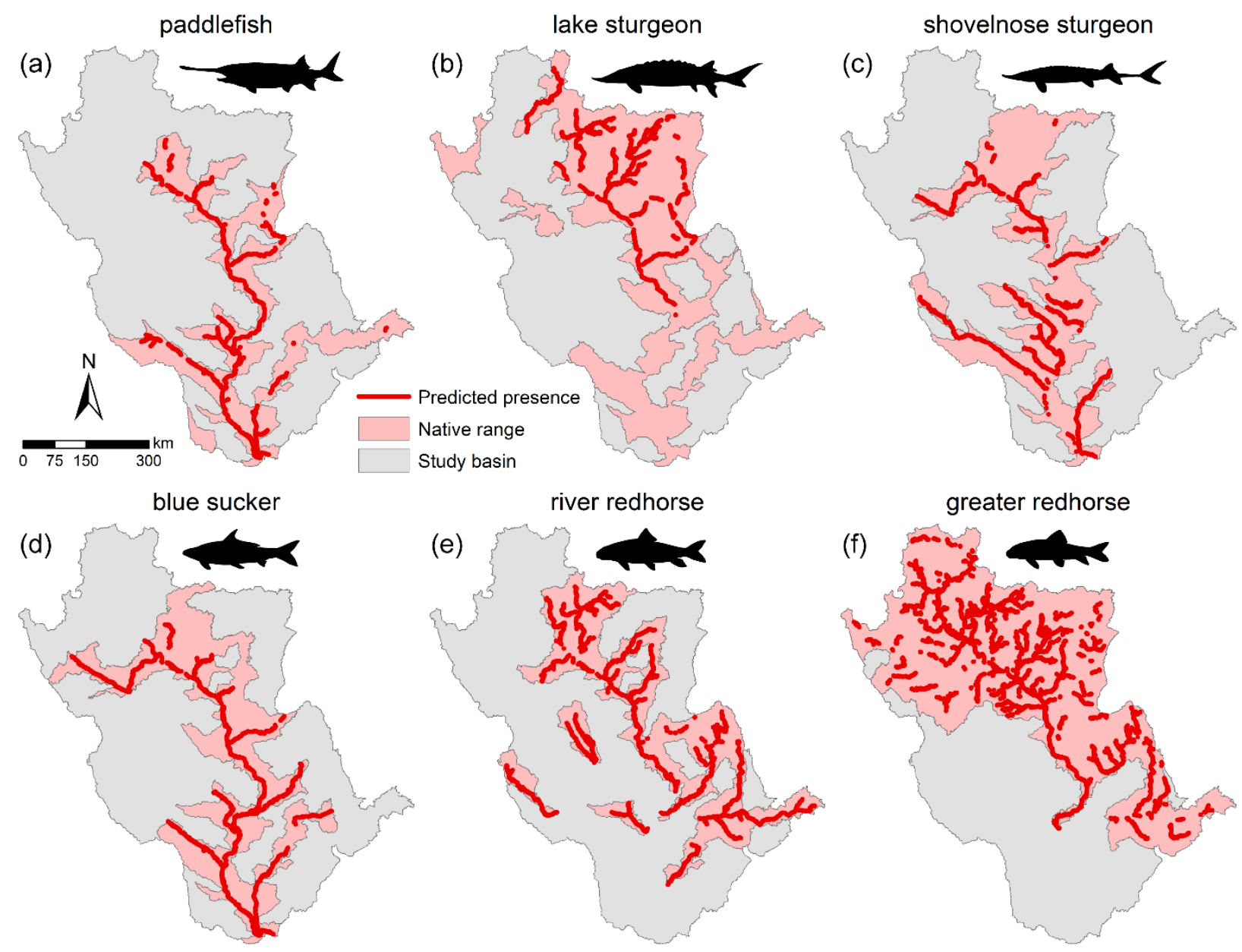
[Figure 4]
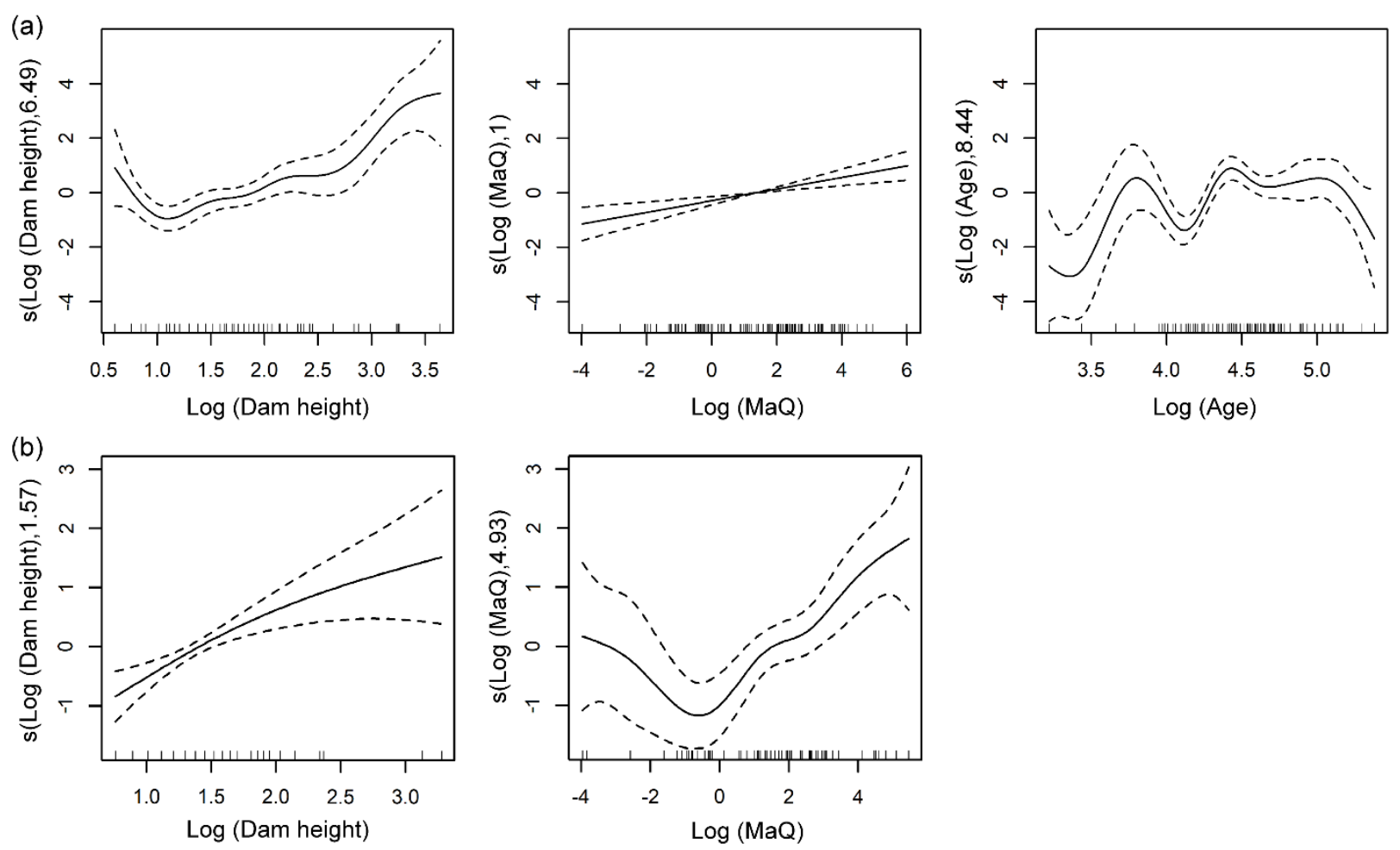
[Figure 5]

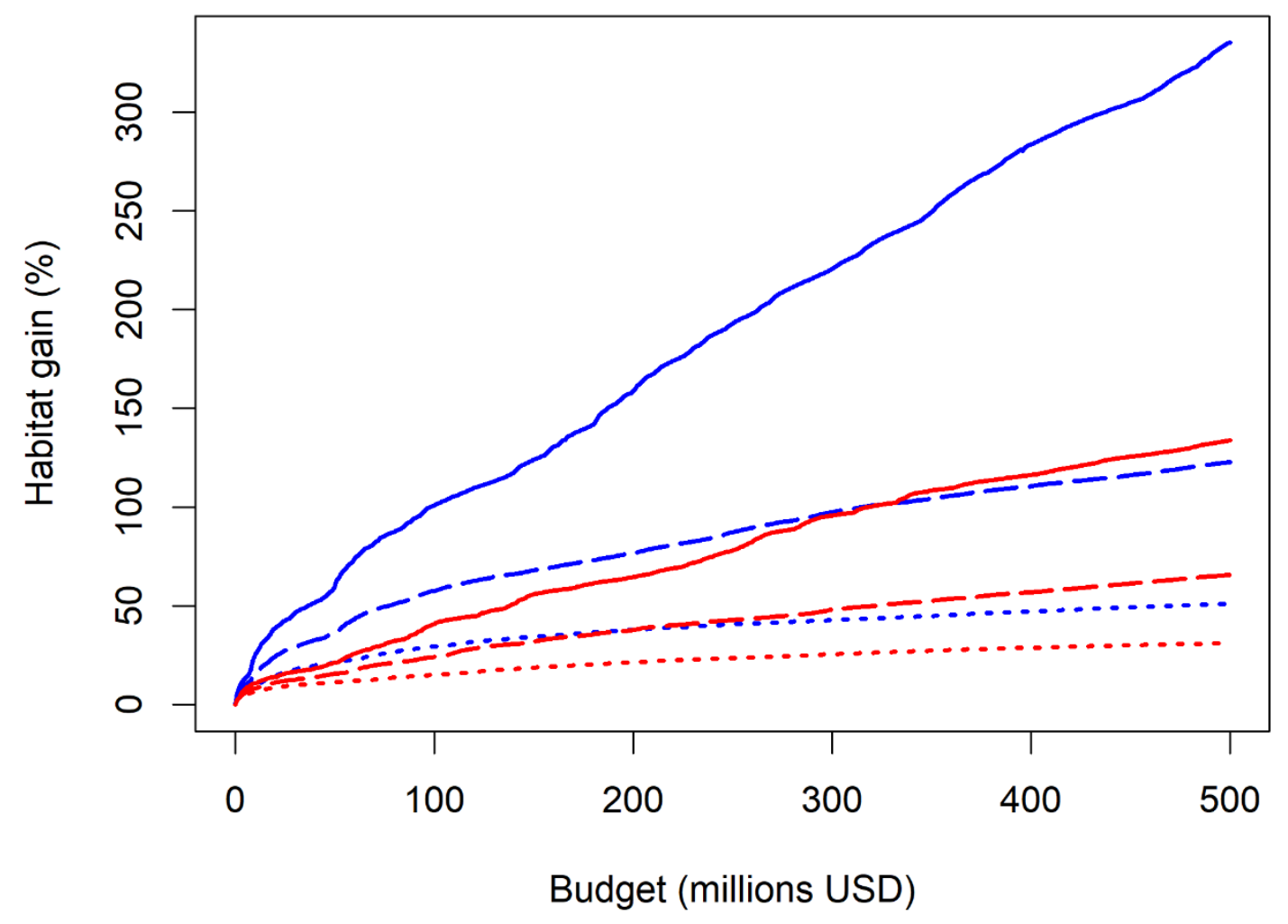


[Figure 6]
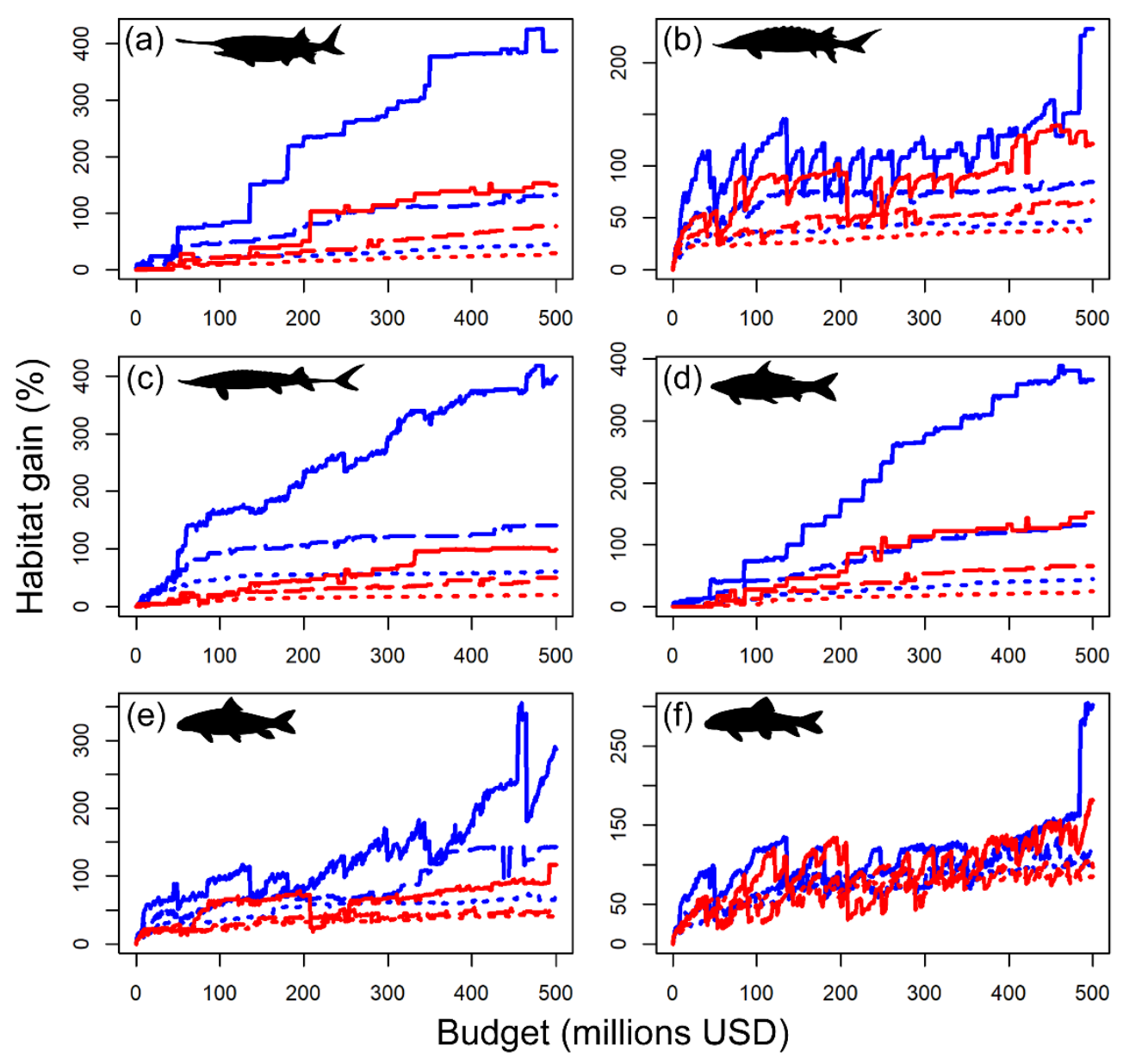
[Figure 7]

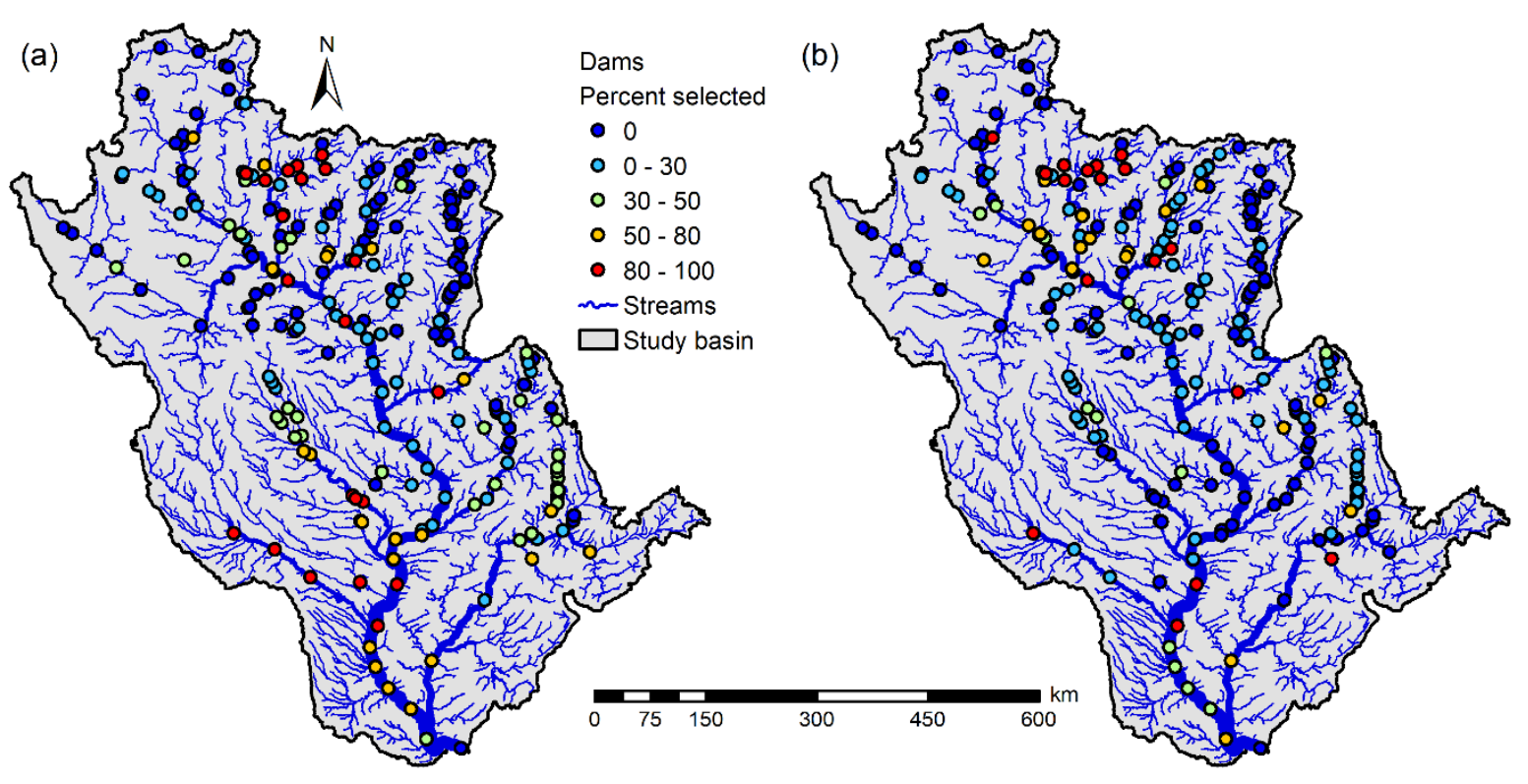

